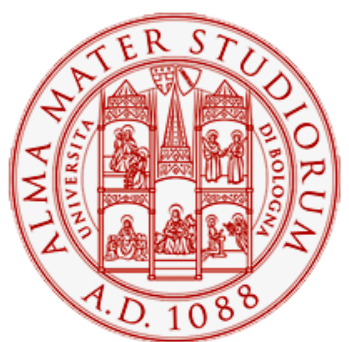

Alma Mater Studiorum - Università di Bologna DEPARTMENT OF ECONOMICS

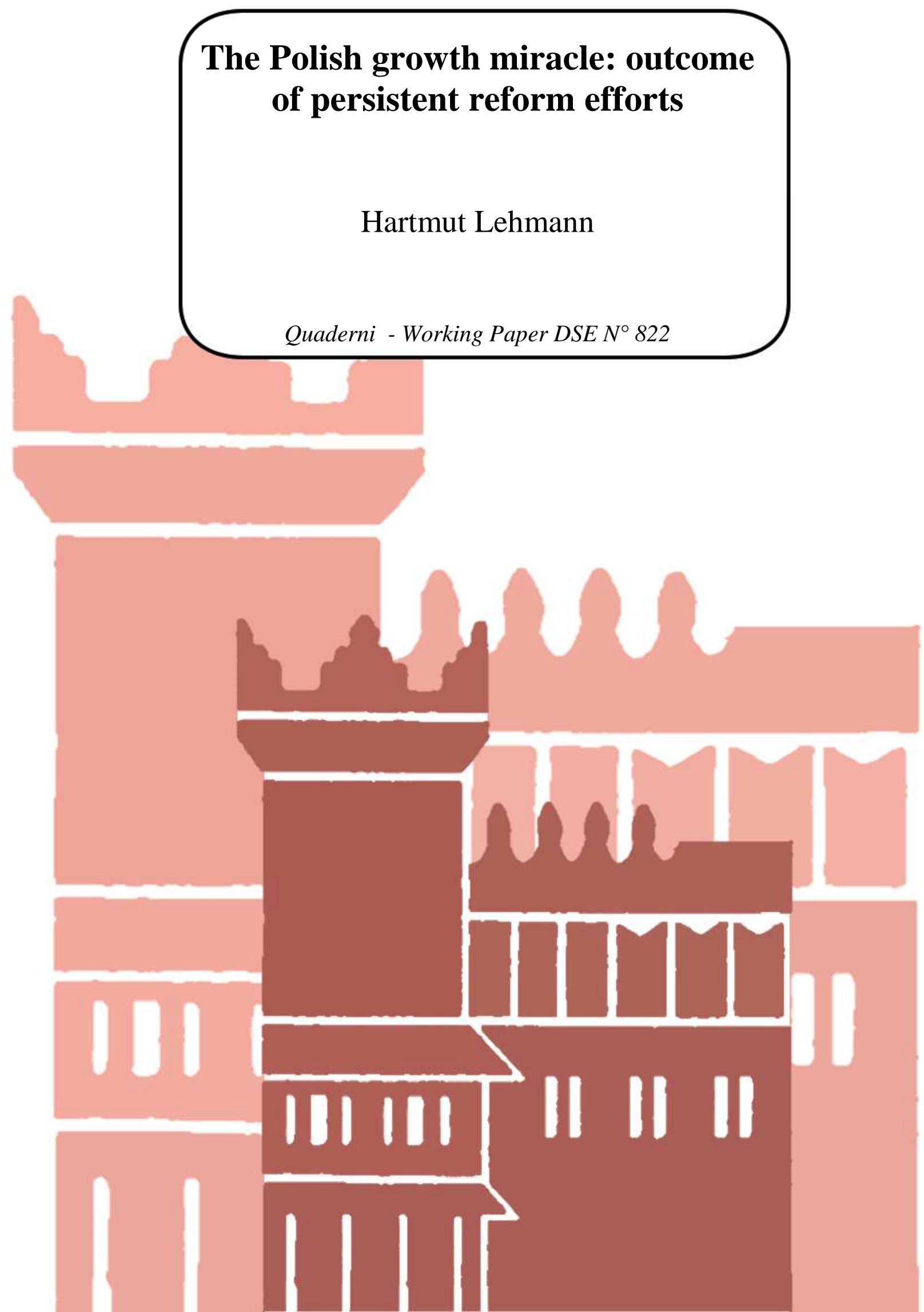




\title{
The Polish growth miracle: outcome of persistent reform efforts*
}

\author{
Hartmut Lehmann \\ Department of Economics, University of Bologna and IZA, Bonn
}

\begin{abstract}
Since the beginning of transition in 1990 from a centrally planned to a market oriented economy, the performance of Poland's economy has been outstanding if we take GDP growth as our measure. In our opinion it is not specific reforms that can explain this performance but the radical ("big bang") reforms at the beginning of transition in conjunction with persistent efforts during the two decades by all governments, no matter what their political orientation, to keep on a reform path. Reforming a centrally planned economy that has very serious macroeconomic disequilibria implies reforms that can be done immediately but also structural or systemic reforms that require years to implement. Both types of reforms will be discussed. In a democratic context reforms can only be undertaken in a sustained way if a majority of voters favours such reform efforts. Even when reform-friendly governments were voted out of office in the Polish case, the new governments in Poland never reversed reforms undertaken by the previous government. This continuous reform stance over two decades is the main cause of the Polish growth miracle. The reasons for the ability of Polish policy makers to pursue economic and administrative reforms in spite of short-run costs to large sections of society will be discussed extensively.
\end{abstract}

JEL classification: D78, J40, P20, P26.

Keywords: Policy Making, Transition Economies, Political Economy of Reform, Poland.

\footnotetext{
* I am grateful to Marek Góra for valuable discussions and for comments on a first draft of the paper. Needless to say that all remaining errors are mine. An Italian version of the paper has appeared in Cambia Italia: come fare riforme $e$ tornare a crescere, Ediz. 2012, and is reproduced here with the expressed authorization of the publishing house SIPI SpA, Rome. Financial support by the Italian Employers' Association (Confindustria) and the Volkswagen Foundation within the project On the Political Economy of Labor Market Reform in Transition: A Comparative Perspective is also gratefully acknowledged.
} 


\section{The Polish growth miracle: outcome of persistent reform efforts}

\section{Executive Summary}

On January $1^{\text {st }} 1990$ the first non-Communist Polish government since World War II under Prime Minister Tadeusz Mazowiecki embarked on an ambitious program of economic reform with the aim to start the transition from a centrally planned to a market oriented economy. The initial conditions for this reform effort were very disadvantageous since in 1989 the Polish economy experienced inflationary bouts close to hyperinflation, brought on by a wage-price spiral, and was characterized by pervasive shortages and a large shadow sector.

Two decades later, the Polish economy is often hailed for its outstanding growth performance. So, given that the Polish economy was in the doldrums in 1989 our essay pursues the question of what can explain this spectacular turn around as far as growth is concerned. However, we also want to address those critical voices that set the Polish "growth miracle" in perspective by citing contracting employment, a steep rise in unemployment and rising inequality in income. However, by the end of the first decade of the $21^{\text {st }}$ century labor market trends improved dramatically, so that over the long haul we can speak of a truly outstanding performance of the Polish economy. The main hypothesis of this paper states that this performance is intimately linked to persistent reform efforts by successive Polish governments.

The most important of these reforms were the initial reforms implemented in January 1990 by a team of economists headed by Leszek Balcerowicz, which stuck with perseverance to the aims of the reforms in the years 1990 and 1991 in spite of mounting pressures from workers and firms demanding that some of the stringent conditions of the reform policies be relaxed. Since these reforms produced visible benefits to the Polish population in the form of rising GDP in a relatively short period of time, a majority of voters found that economic reforms improved their lives and thus was willing to let the government pursue further reforms. Four big reforms were tackled towards the end of the nineties, namely the reforms of the health, pension and educational systems as well as a regional reform. Furthermore, in the run up to EU accession in 2004 a multitude of other structural reforms had to be undertaken by Polish policy makers, among them the introduction of a well functioning financial sector, privatization, reforms of labor market and social policies, of the corporate and personal income tax system and the development of civil legislation.

Three blocks of reforms were particularly important in the persistent reform effort of Polish government. First, the reforms of the Mazowiecki government that brought Poland back from the brink of disaster by macroeconomic stabilization, price liberalization and import liberalization policies, which also set the Polish economy on the transformational path from a centrally planned to a market economy. These reforms unleashed the creativity of new private firms and (with a lag) forced many managers of state-owned enterprises to engage in "deep restructuring", i.e. to alter the production process, to change the mix of the firm's output, to engage in marketing and to shed unproductive labor. These positive effects of the reforms on firm behavior explains the positive growth that the Polish economy exhibited since 1992, two years into the transformational reform process. The second large block of reforms was implemented in 1999, when reforms of health, education, pensions and of regional administration were enacted. These reforms can be considered modernizing reforms as they tackled institutions, which were developed under communism and which were in their existing shape not conducive to improve the competitiveness of the Polish economy and to ensure sustainable government finances. The third block of reforms are those of the first Tusk government towards the end of the analyzed period; they can be considered of the "fine- 
tuning" nature. These reforms improved legislation regarding the health and the pensions reforms, for example, but they also modernized the structure of public finance.

While it is important for the performance of an economy that reforms are implemented it is at least as important that these reforms are not reversed by successive governments. The main reason for the outstanding growth performance of the Polish economy seems to lie in the fact that none of the important reforms were reversed even when the opposition came to power. Most of the important reforms were enacted by center-right governments. Since these reforms often imposed large costs in the short-run, the reforming governments were voted out of office and left-of-center governments took their place. What is crucial for the reform process was the willingness of the new governments to allow the positive growth effects of the reforms to materialize by not reversing part of the reforms or the entire reforms. These positive growth effects in turn convinced a majority of voters to elect a reform-friendly government, which then initiated the enactment of additional reforms.

This virtuous circle driving the reform process was possible because there was a broad consensus by policy makers and pundits across the political divide that Poland had to embark on and maintain a reform course. This broad consensus came about because of a geopolitical reason. Polish society has always identified strongly with Western Europe and, when this became possible, wanted to join the European Union as fast as possible, considering broad reforms as a necessary condition for achieving this aim.

The declared goal of the undertaken reforms was to increase the competitiveness of the Polish economy. But this meant, of course, that state-owned firms or privatized firms had to restructure, which also implied the shedding of redundant labor. This process of shake out of unproductive workers went on throughout the 1990s, resulting in a large drop in employment and a large rise in unemployment. Consecutively, especially older and less skilled workers had great difficulties in flowing out of unemployment. Successive governments reacted to this situation by allowing a large part of the older and less skilled unemployed to take early retirement or to go on disability benefits. This "deactivation" of a substantial part of the workforce throughout the 1990s is the downside of the growth miracle of the Polish economy. 


\section{Introduction}

On January $1^{\text {st }} 1990$ the first non-Communist Polish government since World War II under Prime Minister Tadeusz Mazowiecki embarked on an ambitious program of economic reform with the aim to start the transition from a centrally planned to a market oriented economy. The initial conditions for this reform effort were very disadvantageous since in 1989 the Polish economy experienced inflationary bouts close to hyperinflation, brought on by a wage-price spiral, and was characterized by pervasive shortages and a large shadow sector. In addition, the "dollarization" of the Polish economy was in an advanced state since the Polish population held most of its savings in dollars, implying that monetary policy had become an ineffective tool in the attempt to restore macroeconomic equilibrium to the Polish economy.

When we look at the two decades since the beginning of the reforms, the performance of the Polish economy has been exemplary. Taking GDP growth as our measure of performance, we can infer from figure 1 that Poland had a short transition recession, lasting only two years, while Central and Eastern Europe (CEE), excluding Poland ${ }^{1}$, had a slump that lasted four years. It is also striking that it took the Polish economy only six years to get back to pre-transition levels of GDP, while the economies of CEE, taken together, managed this only after a dozen years. The cumulative growth of Poland's GDP in the period 1992 to 2009 was larger than GDP growth of all the other aggregates shown in figure 1: CEE, the Commonwealth of Independent States (CIS), the EU-15 and the United States. What is also noteworthy is continued positive growth after the onset of the world financial crisis unlike CEE, the EU-15 and the U.S., which all experienced a sharp contraction in 2009. If we take real GDP per capita (in 2000 US\$) as a second measure of performance, then this measure for Poland more than doubled between 1990 and 2009 from 3,097 US\$ to 6,331 US\$, an achievement not reached by any other of the transition economies in CEE. Comparing the trajectories of labor productivity and real wages in figure 2 we can pinpoint one cause of this good performance: labor productivity was above real wages throughout the period outpacing the latter especially in the first decade of new century.

Figures 3 and 4 show the employment-to-population ratios and unemployment rates for the same set of countries as in figure 1. These measures certainly tell a different story than that of GDP growth. Until 2003 employment in Poland fell precipitously to very low levels in international perspective while the unemployment rate was far higher for most of the period, reaching a peak of 20 percent in 2002. Only since accession to the European Union do we observe vigorous growth of the employment ratio and a steep decline in the unemployment rate, which in the years 2007 to 2009 for the first time reached single-digit levels since 1992.

Both the inequality of earnings and the inequality of income rose substantially over the two decades. The Gini coefficient of earnings rose from roughly 21 percent in 1989 to 34 percent in 2006, the last year we have reliable data, while the Gini coefficient of income rose from approximately 27 percent to 34 percent in 2008. In many countries, and also in some transition countries of CEE like, for example, the Czech Republic and Slovenia, earnings inequality tends to be higher than income inequality because of transfers to those with low earning capacity. In Poland, the Gini coefficients of earnings and income are very close to each other, indicating that Polish society spends relatively little on social transfer payments. The fact that the Gini coefficient of earnings has risen over the transition can be seen as a positive development since the rise implies that the labor market remunerates more productive workers better than before the transition. What is worrisome, however, is the fact that the inequality of income had the same level as the inequality of earnings throughout the transition.

\footnotetext{
${ }^{1}$ We include here in CEE the Czech Republic, Estonia, Hungary, Latvia, Lithuania, the Slovak Republic and Slovenia.
} 
In spite of these caveats regarding employment, unemployment and income inequality, it is still true that real GDP per capita doubled in Poland over the last two decades and that growth in GDP eventually caused vigorous growth of employment and a large fall in unemployment. So, over the long haul we still can speak of an impressive performance of the Polish economy, which is intimately linked to the economic reform policies pursued by successive Polish governments.

In my opinion, the most important of these reforms were the initial reforms implemented in January 1990 by a team of economists headed by Leszek Balcerowicz. Since these reforms produced visible benefits to the Polish population in the form of rising GDP in a relatively short period of time, a majority of voters found that economic reforms improved their lives and thus was willing to let the government pursue further reforms. Towards the end of the nineties reforms of the health, pension and educational systems were enacted as well as a regional reform. Furthermore, in the run up to EU accession in 2004 a multitude of other structural reforms had to be undertaken by Polish policy makers, among them the introduction of a well functioning financial sector, privatization, reforms of labor market and social policies, of the corporate and personal income tax system and the development of civil legislation. When encountering social resistance to some or parts of these reforms, this resistance was overcome by claims that these reforms were an integral part of the EU accession process.

Before discussing the specific reform policies I will give by a bird's-eye view of all Polish governments since 1989 and their involvement in economic reform in order to demonstrate the persistence in the reform effort. In my opinion this persistence came about because even though center-right reform-friendly governments alternated with left-of-center "reform-neutral" governments for the first 15 years of the discussed period (1989-2011), the latter governments never completely reversed any of the major reforms enacted previously. At most, they introduced some modifications, as happened in the case of the health and pension reforms.

A word of caution is in order, though. The performance of the Polish economy, while not conceivable without the persistence of government reform efforts, has, of course, also other reasons, especially if we look at the performance in the first decade of the new century. For example, a relatively low government debt, a good export performance, also caused by frequent devaluations of the Złoty, a large internal market, consumer optimism and greatly improved industrial relations are all reasons that help explain why the Polish economy has performed so well in the last years, including those of the crisis.

\section{Polish governments and economic reforms: a bird's-eye view}

Table A1 in the appendix shows the 16 governments of Poland since the communists relinquished power. Most of the governments were short-lived, that is they were not formed for an entire legislature of the Sejm (the Polish parliament), pointing at the relative unstable political landscape of Poland. Also, many parties were dissolved or merged with other parties contributing further to a somewhat chaotic political landscape. The governments that are listed in the table can be divided into reform-friendly governments and "reform-neutral" governments, that is governments that did not pursue major reforms but that also did not try to go back to the status quo ante once they came to power. The first two governments in the post-communist era, the governments of Hanna Suchocka, Jerzy Buzek and Donald Tusk can be counted definitely as reform-friendly governments, while that of Jarosław Kaczyński to a lesser degree. The parties forming these governments are 
predominantly on the center-right of the political spectrum, while the parties forming reform-neutral governments find themselves predominantly on the left.

Inspection of the large table 1 shows that two governments were especially responsible for the economic reforms that Poland underwent. First and foremost, the Mazowiecki government enacted 10 reforms in January 1990 simultaneously. These reform acts are associated with the "shock therapy" or "big bang" approach that will be discussed in detail below. Here we just mention the principal aims of the most important of these acts. The first act abolished subsidies to loss making state-owned enterprises (SOEs) and also foresaw the possibility of bankruptcy of such firms. The second act wanted to prevent the monetization of the budget deficit, while the third eliminated bad loans to state firms and imposed positive real interest rates. The fourth act introduced large marginal taxes on excessive wage growth to rapture the link between wage growth and inflation. The act on foreign currency established internal convertibility of the zloty and got rid of the last vestiges of the state monopoly in international trade. The acts on employment and on severance pay and unemployment benefits were insofar important as they regulated layoffs and the income support for workers flowing into unemployment. These acts were indispensable if the solidarity trade union was to agree to the possibility of labor shedding by firms, something not possible under central planning but absolutely vital for the beginning of a reallocation process of labor from unviable to new profitable activities. Most of the mentioned acts had as their main aim macroeconomic stabilization, the last two described acts were put in place to begin the construction of a social safety net considered important for cushioning the effects of transition for workers.

We speak of "shock therapy" or "big bang" because reforms were applied on such a broad scale. This could be done because the country was confronted with a major crisis. The political economy of reform literature tells us that it might be very difficult to revert to the status quo ante when such broad reforms are implemented. The Olszewski government, also a right-center government formed after the November 1991 elections, was not willing to reverse them in any major way. In particular, it was not inclined to bail out any SOE with subsidies even if it was in great financial distress. This policy of not giving in to tremendous pressures allowed the effects of the reforms to materialize with the economy experiencing positive growth. As we shall see below, the fact that the Olszewski government did not reverse policies regarding SOE subsidies meant that managers of SOEs understood that no help from the state was forthcoming and that they had to manage their firms in the most efficient way possible.

The second most reform-friendly government was headed by Jerzy Buzek. Leszek Balcerowicz who had been Minister of Finance in the first two post-communist governments and the architect of the "shock therapy" reforms, again held the same post in the Buzek government. Buzek had built his election campaign around promises of major reforms. So when he won the elections he enacted four important reforms: the pension, education, health and administrative reforms. They were important insofar as they had a strongly modernizing aspect and/or because they set public finances on a better footing. Between these major reforms and the reforms of the Mazowiecki, Bielecki and Suchocka governments lay more than five years. So, one way to think about Polish reform efforts is to say that after major reform efforts policy makers allow the reforms to play out and give a necessary breathing space to society.

It is striking, though, that not one major reform has ever been revoked by a successor government. In my opinion this is the key to the Polish growth miracle; we have a virtuous circle where large economic reform projects produce in the medium run discernible benefits. While reform-friendly governments might be thrown out of office because of the short-run costs of the reforms, the successor governments allow these reforms to play out, producing visible positive results. This eventually convinces voters to elect another reform-friendly government, which then launches a 
new large reform package. At the same time reform-neutral governments even if not adopting large reform projects push the reform agenda also ahead by giving wide publicity and promoting discussion of reform strategies for Poland. So, left-of-center governments help prepare the ground for new reform projects being enacted by a successor center-right government. That the left-ofcenter governments did not enact themselves major modernizing reforms but through publicly held discussions only prepared the ground for their enactment can be explained by the fact that many of their voters (workers, pensioners, public employees, and to some extent farmers) had to bear a disproportionate share of the short-term costs of any major reform effort.

There are at least two reasons why the described virtuous circle was sustainable in the Polish case. The most important reason in my opinion is geopolitical, namely the identification of Polish society with Western Europe. Poles have always considered themselves culturally linked with the West of Europe and perceived the forty years of Russian influence after the end of World War II as something profoundly undesirable. Consequently, the Polish public in a large majority was intent to join the European Union as soon as possible, being willing to undertake the necessary sacrifice to reach this goal. This generated a strong consensus among policy makers and pundits of all moderate party affiliations to pursue systemic and modernizing reforms, which prepared Poland for accession to the Union. It is noteworthy that we see a very similar scenario in Estonia where the political elite across the political divide has taken recourse to the same broad consensus on the necessity to reform the Estonian economy in a coherent and consistent fashion (Eamets, 2011).

A second reason is linked to the inner workings of the Polish government. The political science literature highlights the importance of the decision making process at the cabinet level when providing a taxonomy of parliamentary-based coalition governments. In Poland, like in many countries, we have cabinets where apart from the prime minister the minister of finance has more decision power than the other ministers. In principle, the finance minister can block any ministerial projects that threaten the budget and/or undermine the general direction of macroeconomic policies. All consecutive governments independent of party composition had finance ministers with very clear notions about the need to keep on the reform track. Consequently, any attempt of a complete reversal of some undertaken major reform never had a chance even under a left-of-center government.

Donald Tusk is the only prime minister whose coalition after having passed several important reforms was reelected. The Tusk governments are certainly reform-friendly as they have enacted important laws on public sector finances, on the streamlining of the pension system (above all eliminating inefficient bridging schemes) and on the partial commercialization of the health care system. But the reform efforts of his governments are more of the fine-tuning nature with the main reforms having been done apart from the Mazowiecki and the Buzek governments by the Bielecki government (enacting personal income and corporate tax reforms) and the Suchocka government (enacting a sensible privatization law and the law on VAT). It is certainly striking that all these reform-friendly governments have their roots in the Solidarity movement, while the main coalition partner of the reform-neutral governments descends from the Polish Communist Party (the Polish United Worker Party - PZPR). 


\section{Setting the stage for the Polish reform efforts}

\section{III.1. The failure of market socialism}

Communist governments in Hungary and Poland experimented with the introduction of market socialism, consisting in an attempt to apply market principles to centrally planned economies. In a celebrated paper Kornai (1986) demonstrated why this attempt failed miserably, pointing to a political economy argument and to technical reasons. For Kornai, in a centrally planned economy bureaucratic coordination is the principal mechanism that organizes economic, political, cultural and social life. In a market economy, in turn, the dominant organization principle is market coordination. In a world where the public ownership of the means of production strongly dominates and where the Communist "nomenclature" jealously guards its economic and political monopoly, the coexistence of bureaucratic and market coordination is difficult. Whenever there is a conflict between bureaucratic and market coordination, the former wins since the main agents in a centrally planned economy, i.e. central bureaucrats but also firm managers, are foremost members of a bureaucratic apparatus that has as its main aim the preservation of its monopoly position in society.

There are also technical reasons why the application of market principles to a centrally planned economy does not show the desired result, which is to have price signals determine a more efficient allocation of resources. In a market economy market coordination is based on price signals, which strongly influence the behavior of buyers and sellers. Since prices and the interests of bureaucrats from the center, managers and workers are hardly interlinked in a centrally planned economy, price signals cannot really influence the behavior of the agents. For example, the well-being of a manager directing a firm depends nearly exclusively on plan fulfillment and not on profits achieved by maximizing the difference between the price and the costs of production since loss making firms are always bailed out by the center. So, there are no incentives for this manager to respond to price signals and to economize on the costs of production. Thus, trying to incorporate market coordination via prices into a centrally planned economy turned out to be rather futile.

This failure of market socialism is important for our story, since many of the leading economists in Poland were involved in the reform efforts associated with market socialism in the early 1980s. They learned the hard way that piecemeal reforms of the central planning system did not lead to sustainable increases in efficiency. That is the main reason why in Poland, and in all other CEE transition countries for that matter, after the collapse of Communism those directly working on economic reform saw only one sensible reform path, the direct transition to an economy based on market principles and on predominantly private ownership of the means of production.

\section{III.2 Initial conditions of the reform process}

The Polish economy, like all economies of CEE, was plagued by the legacies of central planning, which had a profound impact on the reform policies chosen and on the length of the transition. I summarize the most important initial conditions at the beginning of the reform process in order to demonstrate the difficulties that the economic reform team was confronted with when launching the transition in January 1990.

A crucial initial condition was the macroeconomic disequilibrium that we present in a schematic fashion in figure 4. A centrally planned economy is supply constrained, that is, at the given (administered) price level $\mathrm{P}_{\mathrm{A}}$ output is rationed and the quantity demanded far exceeds the quantity supplied. This has at least two important implications for reformers who want to arrive at an economy based on market principles. First, firms in a supply constrained economy can sell all of 
their output independent of the quality of their products and irrespective of consumer preferences. Consequently, product quality and satisfying consumers' demand are not a priority for managers. Once prices are liberalized and market forces are allowed to take a hold, the economy becomes demand constrained and managers need to ensure that their products are competitive in terms of price but also in terms of quality. In addition managers have to get involved in the marketing of their products, something that was completely unnecessary when the economy was supply constrained. Whether managers of SOE's had the right skills to function in a market-based economy was certainly an open question when the reforms were launched; it was clear, though, that the incentive structure for managers would have to change if their firms were to survive in a demand constrained environment. The second implication of a supply constrained economy is that it creates potentially a large stock of forced savings, the so called "monetary overhang", since in each period, as demonstrated in figure 4, at prevailing prices the public is willing to buy QD but the economy is only supplying QS. When a lot of money chases few goods and the government loses control over prices, inflationary pressures build up and these inflationary pressures are transformed into open inflation as Poland experienced in 1989. The annual inflation rate in that year was about 3000\%, eliminating the monetary overhang. However, as long as the disequilibrium prevails, the nominal value of goods wanted is larger than the nominal value of goods offered. Price liberalization will result in "corrective inflation" correcting for the inequality of the nominal value of the flow of income and the nominal value of the flow of goods. In figure 4 this correction is shown by the shooting up of the price level from $\mathrm{P}_{\mathrm{A}}$ to $\mathrm{P}_{\mathrm{E}}$. To reach the equilibrium the nominal value of income (wages) has to rise less than the nominal value of the goods offered. Corrective inflation thus implies a large fall of real wages. An interesting account of corrective inflation in Poland and its causes is given in Gomułka (1992).

The centrally planned economies operated internationally according to an overall plan within the Council for Mutual Economic Assistance (CMEA) and based on the principle of division of labor. In other words, these economies allocated resources according to what this overall plan said and not according to relative world prices. Opening these economies to world markets had some short-term costs and some longer-term benefits. Since most SOEs did use inputs without considering relative world prices (a good example is the use of energy here) when these economies were opened up to world markets many of the SOEs became unviable unless they restructured rapidly, that is unless they used resources in a rational way reflecting relative scarcities as expressed by world prices. In the longer term trade liberalization, which implies the removal of non-tariff barriers to trade and the lowering of tariffs, thus forced upon managers of SOEs a rationale use of resources. In addition, once prices were liberalized trade liberalization made the resulting highly monopolistic goods markets more competitive through competition from foreign firms thus forcing SOEs to adopt more efficient production processes and to improve product quality.

At the beginning of the transition SOEs were the dominant economic units in the Polish economy. So, most of the physical capital in the economy was owned by the state. All economists involved in the Polish reform effort were convinced that private property of the means of production was a necessary condition for long-term growth. This is not surprising since the large literature on empirical and theoretical aspects of privatization points unequivocally to a superior performance of firms with privately owned capital in industrialized countries. This literature took its inspiration from Hayek (1945) who shows very convincingly the link of ownership type and long-run growth by demonstrating how private entrepreneurs can adjust to dynamic changes relying on a decentralized and flexible price system much more efficiently than a central planner. At any rate, the need for large-scale privatization was never in doubt as far as Polish reformers were concerned. Thus, the reformers had the daunting task that nearly the entire stock of capital had to be privatized. This was difficult for several reasons. First, the sheer size of the task was unprecedented in history. Second, there were problems of the valuation of SOEs linked to the issue of how to sequence the 
privatization process, that is whether to first restructure and then to privatize or vice versa. The third area of problems were related to how to privatize and what different privatization schemes implied for corporate governance. Selling the stock to domestic investors in a short period of time was not possible since corrective inflation had wiped out most of the savings; selling the capital stock to foreigners, assuming they were willing to acquire Polish capital, was politically not feasible. The reason for this has to do with the fact that most of the capital stock had been accumulated under communism and that this accumulation had been achieved by emphasizing the investment goods sector at the expense of consumption. Clearly, the public wanted to be compensated for these sacrifices that had lasted for decades. So in Poland, like in all other CEE economies apart from Hungary, the industrial capital stock was given away to all citizens, leading to some important corporate governance issues. In essence if each citizen has a small share of the capital it is impossible to exert control over the privatized firms' managers. In Poland this issue of lacking control over management was resolved by setting up National Investment Funds (NIFs) which managed 512 medium and large SOEs proper and commercialized SOEs. Each member of the adult population received a "universal share certificate", which was eventually converted to a share in each of the 15 NIFs. ${ }^{2}$ At any rate the difficulties connected to privatization briefly discussed here had the important consequence that SOEs could not be privatized over night and that the reformers had to deal with SOEs as the main economic units of the Polish economy for some time to come once reforms were launched.

In a centrally planned economy, even in its reformed version of market socialism, many SOEs had "soft budget constraints", that is they were allowed by the center to have total costs larger than total revenues on a continuous basis. The center simply redistributed funds from profit making to loss making firms thus guaranteeing the long-run survival of the latter. "Soft budget constraints", of course, meant that managers did not have to care about an efficient use of resources. The imposition of "hard budget constraints" (total revenues $\geq$ total costs) was thus one of the most pressing problems of the reformers. The Polish reformers intended to achieve the imposition of "hard budget constraints" by slashing subsidies to SOEs. If managers became convinced, so the argument, that the state would no longer bail them out if they made losses, they would start to use resources in an economic fashion.

Slashing subsidies to SOEs was not only considered an important tool to impose economizing behavior by managers it was also thought to be vital for the fiscal position of the government once the reform plans were implemented. The main source of tax revenues was the turnover tax paid by SOEs; price and trade liberalizations would bring, at least temporarily a fall in revenues of SOEs and thus a large fall in tax revenues. The reformers intended to introduce unemployment benefits for laid-off workers and early retirement schemes, which would be new large items on the expenditure side of the budget. So, even if the reform government slashed subsidies to SOEs and if it was able to suspend the servicing of the external debt, large budget deficits seemed to be preprogrammed. Since at the beginning of the reforms the banking and financial sectors were not

\footnotetext{
2 The Polish Mass Privatization Program was maybe the reform policy where Poland was less successful than other countries since it took 4 years after the beginning of transition to enact a law on it and nearly 6 years to set up the NIFs. I will not discuss privatization, which, for political reasons, was very piecemeal in Poland and drawing out over more than a decade. This slow performance with respect to privatization can be interpreted in several ways. On the one hand, if the mass privatization of SOEs had been done early and rapidly, the performance of the Polish economy might have been even more impressive than the one we observe. On the other hand, though, my hunch is that given the resistance of workers to privatization, forcing upon society the privatization of the majority of SOEs in a short period might have derailed the whole transition process. Finally, as I will discuss below, the stabilization policies adopted by the Mazowiecki government eventually forced managers of many SOEs to begin with the restructuring of their enterprise.
} 
developed, these governments deficits would have to be monetized. So, to ensure that inflationary pressures were rained in, the government deficit had to be reduced as much as possible.

The last legacy that I want to deal with is the absence of a social security system under central planning. In CEE there existed no open unemployment, and workers for the most part had life-long jobs at one firm if they wished. Estimates for Poland actually show that labor hoarding (hidden unemployment) amounted to at least 10 percent of the employed. Apart from pensions, all other benefits were given to workers by the firm where they worked. So, one important task for the reformers was to preside over the divestiture of "social assets" in possession of firms since under conditions of liberalized markets firms could no longer afford to provide these services to their workers. More importantly, the government had to build a social safety net from scratch. This social safety net became necessary since reforms created unemployment and increased poverty in the country, at least temporarily. Thus a social safety net had to be developed that effectively and in a targeted way alleviated poverty and helped the unemployed temporarily. The necessary help for the unemployed might serve as an example of the complexity of creating a social safety net. This help had to be administered by labor offices, which in Communist times existed but whose function had been to find workers for firms in a situation of excess demand for labor and no open unemployment. Once reforms set in and workers were laid off from firms and new labor market entrants did not readily find jobs, these labor offices had to essentially perform three tasks: (a) administer unemployment benefits; (b) match unemployed workers with vacant posts ("job brokerage"); and (c) administer active labor market policies (ALMP). Not only had resources be made available for these tasks, but the staff of the labor offices had to be retrained to fill out these new functions. A final task regarding the build-up of an efficient social safety net was the elimination of many nontargeted subsidies that were prevalent in the centrally planned economy.

\section{III.3 A taxonomy of reforms and the political economy of reforms}

As we have seen in the previous section, Polish policy makers had to battle for reforms on many fronts. One way to think about the many reforms that have to be undertaken is to introduce a timeline along which reforms can be implemented ${ }^{3}$. Figure 5, showing such a timeline, demonstrates that some reforms can be implemented at once while other reforms, in particular of the systemic type, can take a very long time. Price liberalization, trade liberalization and macroeconomic stabilization are all policies that can be implemented essentially over night, while reforming the labor market or generating a business friendly environment can take more than a decade. In the case of Poland, which did have a capitalist economy in embryonic form before World War II, the development of a legal infrastructure, which guarantees strong property rights and regulates commercial activities turned out to be less time consuming and problematic than for example in the successor states of the Soviet Union. The main reason was, of course, that in Poland law makers could go back to pre-world war II legal texts, while Russian or Ukrainian law makers could not do that. Figure 5 at any rate suggests that one needs a long breath and a clear vision when one wants to reform a formerly centrally planned economy and set it on a long-run growth path since all pieces of a complex puzzle have to put in place and that at different times. In my opinion, Polish policy makers irrespective of party affiliation and high government officials had this long breath and clear vision.

We can also use the first panel of figure 5 to distinguish between "big bang" and "gradualist" reforms in a transition context. When the first three policies are simultaneously implemented we speak of "big bang" reforms while if they are applied sequentially we characterize reforms as "gradualist". The former type of reforms tends to exhibit complementarities, so if it is politically feasible it is better to pursue these policies simultaneously. The vast field of the political economy

\footnotetext{
${ }^{3}$ The first paragraph of this section is based on Schaffer (1993).
} 
of reforms in general and in a transition context in particular, however, has identified many political feasibility constraints of reforms ("ex ante constraints") and reversibility constraints of reforms ("ex post constraints") that might make the "big bang" approach an unrealistic option (see, e.g., Roland, 2002). Those who favor gradualism make the point that it might be politically more feasible to implement the one reform which promises the best pay-off to the population. Building on the success of such a reform it is then possible to implement additional reforms. We might illustrate the advantages and disadvantages of gradualism by looking at price liberalization and trade liberalization. If we start off to reform the economy by first liberalizing prices, shortages will disappear and the public will be convinced that reforming the economy brings benefits. If, on the other hand, reformers liberalize prices and trade simultaneously (and for budgetary reasons slash subsidies to firms) many SOEs might become unviable and need to lay off a large part of their workforce. The public might then turn against further reforms. Of course, the downside of only liberalizing prices is that even after price liberalization relative prices might not reflect the true relative scarcity of goods since firms are not exposed to world markets. In addition, given the highly monopolistic structure of goods markets, price liberalization might translate into large monopoly profits for SOES, which means that there would be little need to become more efficient. A "big bang" approach combining price and trade liberalization would have a larger positive effect on the efficiency of the economy because of the complementarities of the individual reform policies.

The Polish reformers were "fortunate" insofar as the last communist government had allowed a deterioration of the status quo to a degree that made in my opinion the simultaneous introduction of several reforms inevitable. ${ }^{4}$ In other words, the reformers could not opt for a gradualist reform strategy; they were pushed by the deteriorated status quo into the pursuit of a "big bang" approach if they wanted to prevent hyperinflation, the impoverishment of large sections of society and a complete dollarization of the economy. In addition, the deteriorated status quo had weakened any resistance within the state apparatus to the rapid action plan proposed by the reform group. More important than introducing a set of radical reforms is to stick to these reforms when social pressure builds up to reverse some of the reform measures. Here geopolitical considerations can explain the success of the government led by Tadeusz Mazowiecki. The Polish public perceived the Mazowiecki government as the first Polish government in half a century not dominated by a foreign power. The Polish public essentially provided a blank cheque to this first non-Communist government that not only allowed the government to implement the reforms but gave it also enough time for the reforms to play out. This breathing space was essential for the reforms to eventually have a positive impact on GDP growth after a very short transition recession that lasted only two years. The strong growth of GDP from 1993 until the Russian crisis of 1998 convinced policy makers and a majority of Polish society to pursue further reforms, which were then implemented at the end of the nineties.

A second geopolitical reason impacting positively on Polish reform efforts has been the already mentioned identification of Polish society with Western Europe and the intent of a majority of Polish society to join the European Union. So, any Polish government could present structural reforms as necessary steps for accession to the Union while at the same time pronouncing that it undertook these reforms only reluctantly. At the same time, the accession process helped Poland to modernize her political, legal and administrative structures in an accelerated fashion. The successor

\footnotetext{
${ }^{4}$ Schaffer (1993) states that Polish policy makers had the choice between stabilization first, followed by liberalization matters or by applying stabilization and liberalization measures simultaneously. At the same time he stresses that the Mazowiecki government "faced a crisis situation. Prices were increasing at near-hyperinflation rates (..). The government budget deficit had ballooned in the first half of the year, to about $15 \%$ of GDP. Output was falling and wages and labor costs were at unsustainable levels. Foreign exchange reserves were dangerously low. Shortages and queues were widespread." Given this gamut of difficulties, I find it hard to believe that the solidarity-led government really had a choice between a gradual and a "big bang" reform approach.
} 
states of the Soviet Union had no prospects to join the EU in the foreseeable future. Therefore, the modernization process, which imposes large short-term costs on society, was considered less desirable and was politically much more difficult to implement.

One final important political economy consideration that should be discussed is the presence of civic society in Poland even under communism. A comparison of Russia and Poland is particularly instructive in this context. In the Soviet Union any remnants of civic society were thoroughly destroyed during the industrialization and collectivization campaigns in the thirties as well through the Great Terror in 1936-1938. At the end of the thirties Russian society was completely "atomized" and no social activity was possible outside the Communist party since that time. In communist Poland there were two powerful social organizations outside the realm of the Communist party, the Catholic Church and the Solidarity trade union. Both these organizations upheld civic virtues during the communist dictatorship, civic virtues that were completely absent in the Soviet Union. Some authors explain the state capture by oligarchs in Russia with this absence of civic virtues in society at large. The fact that Russian oligarchs got a hold on the levers of state power for their own private aims had political repercussions in that a consistent and broad reform agenda could not be implemented. In Poland, on the other hand, the existence of civic virtues prevented the emergence of an oligarchic class and was thus at least partially responsible for the pursuit of consistent and broad reforms. Roland in the cited paper makes forcefully the point that to fully understand the successes and failures of reform policies it is not enough to analyze the mix of economic policies; instead it is crucial to embed these economic policies in a broad historical context.

\section{The reform policies of the Mazowiecki government}

\section{IV.1 The Program in some detail}

In a memorandum on the economic reform program sent to the Bretton Woods institutions in September 1989 the Polish government outlined its reform program in broad terms, stating that it intended "to transform the Polish economy into a market economy, with an ownership structure changing in the direction of that found in the advanced industrial economies." The program had three general ingredients (Government of Poland, 1989):

1. monetary and price stabilization;

2. structural adjustment;

3. foreign economic assistance and reduction of foreign debt.

The program under (1) was above all a macroeconomic stabilization program, but as we shall see later on it was also conceived to influence the microeconomic behavior of managers of SOEs.

One of the most important elements of the stabilization program was price liberalization. In August 1989 the new government had already liberalized food prices. In January 1990 the remaining administrative price controls were removed with a few exceptions. By January 1991 the shares of prices freely determined were $100 \%$ of agricultural producer prices, $88 \%$ of industrial producer prices and $83 \%$ of consumer prices respectively. At that time administered prices were applied to alcohol, electricity, gas, heating and hot water, rents in state housing, postal services and telecommunications as well as state rail and road transportation. Polish reformers (jointly with IMF experts) foresaw a rise of the Consumer Price Index of 45\% in January 1990 and a rise of 94\% over the entire year. These forecasts were far off the mark, since in January 1990 alone consumer prices rose by $80 \%$ and over the whole year of 1990 by roughly $250 \%$. This larger corrective inflation implied a much larger fall of real wages than foreseen: in 1990 real wages in industry fell by 
between a quarter and $32 \%$ (the true magnitude of the fall is disputed in the literature). It also led to a liquidity squeeze in the economy in the first half of 1990.

This liquidity squeeze came about because the government in collaboration with the National Bank of Poland decided on a very restrictive monetary policy by restricting domestic credit expansion. One declared aim of this restrictive monetary policy was the achievement of positive real interest rates, which would entice firms and households to hold at least the new stocks of savings accumulated after January 1990 in the local currency of the zloty. Since inflation was much larger than anticipated the established nominal credit expansion resulted in an excessively large fall of real money balances according to Gomulka (1992). The government, always conscious about the danger of inflation reigniting, was not willing to adjust credit expansion targets upward thus leading to a credit crunch soon after the onset of the reforms in January 1990. Being put under immense pressure by SOE managers and representatives of the solidarity trade union, the government relented somewhat and eased credit expansion in the second half of 1990.

A third important element of the stabilization strategy was to regain control of the government budget, which the previous government had lost in 1989. The principal tool to reaffirm this control was the deep cuts in subsidies to SOEs which fell from 15\% in 1989 to $6 \%$ in 1990 . These were further reduced in the following year. In addition, tax exemptions for enterprises were nearly totally eliminated in the first year of the reforms. While the main aim of this fiscal policy was to reduce the deficit, the slashing of subsidies was also thought as a way to "whip" SOE managers into profit maximizing or cost minimizing behavior. As we shall see later this secondary aim was only achieved after a considerable period of time. Because of the tremendous fall in real wages SOEs actually had extraordinary profits in the first half of 1990, leading to large tax revenues and a positive government budget in this period. As the liquidity squeeze started to hurt SOEs tax revenues fell in the second half of 1990 resulting in a budget deficit. As mentioned in the section on initial conditions, the lack of a developed financial sector implies that government deficits have to monetized; this is exactly what the Polish government had to do, thus contributing to inflationary pressures.

Another important element of the stabilization program was the imposition of a unified exchange rate, which was based on the black market rate of 9500 zloty to 1US\$. Already prior to the date of the "big bang", the Mazowiecki government had eliminated last residues of the international trade monopoly of the state. In January 1990, the domestic market was abruptly exposed to import competition when non-tariff restrictions (import licenses) were eliminated over night. In addition tariffs were set at low levels: the average tariff rate for all goods was about $12 \%$, for consumer goods roughly $16 \%$ in 1990 . Also, taxes and most restrictions on exports were removed. Some authors have considered the established exchange rate as far below the equilibrium value. According to them this undervaluation can partially explain the stability of the nominal exchange rate in spite of continuing inflation in 1990. The reformers were intent on keeping the nominal exchange rate fixed as long as possible since it could serve as an important nominal anchor against inflation. ${ }^{5}$ If the exchange rate was undervalued at the beginning of the reforms it also protected domestic producers to some degree and boosted export while at the same time providing a nominal anchor against inflation and helping to restore confidence in the zloty. Imposing the unified exchange rate at the indicated level boosted exports and limited imports in 1990 leading to a large trade surplus and a strong accumulation of foreign reserves. This good trade performance, however,

\footnotetext{
${ }^{5}$ Let $P=\alpha * e^{*} \bar{P}_{W}+(1-\alpha) P_{D}$ be the price level in the economy, which is a linear combination of world prices (assumed constant) and the domestic price level and let $e$ be the nominal exchange rate in Zloty/1US\$. As long as $e$ is constant, the prices of imported goods do not contribute to inflation. A devaluation of the Zloty will raise e and thus increase the overall price level.
} 
did not last mainly because of an appreciating real exchange rate and three constraints that Polish firms had to deal with. First, the Soviet Union introduced world prices in all CMEA transactions and insisted on settling outstanding balances in hard currency. In addition to this cost shock Polish SOEs also "lost" their suppliers and their clients in the Soviet Union since the Soviet economy was no longer functioning in 1990 and 1991. While this collapse of intra-CMEA trade facilitated the reorientation of Polish SOEs to Western markets, at least initially it meant a large fall in export earnings. The second shock occurring - and this was a truly exogenous shock - was the social and monetary union of West and East Germany in July 1990, which resulted in a complete collapse of industrial production in East Germany. So, like in the case of the Soviet Union, Polish SOEs lost their traditional German suppliers and clients. A third constraint affecting negatively the trade performance of Poland was the protectionist attitude of the European Community, which prevented free imports from Poland above all in those sectors where Poland had a comparative advantage (agricultural and low skilled manufacturing products). Given these three constraints and a large appreciation of the real exchange rate it does not come as a surprise that the trade surplus of 1990 turned into a trade deficit in 1991. Given this deterioration of the trade performance tremendous pressure built up on the government to devalue the zloty. Since the nominal exchange served as an anchor of the stabilization programs policy makers were reluctant to give in to this pressure and only in May 1991 was the zloty devalued for the first time.

The fifth important element in the stabilization program was the tax-based incomes policy, which is to some degree a misnomer as this policy involved a tax surcharge on wages growing above a certain norm, which was established over the year by the Council of Ministers by decree. A taxbased incomes policy in general relies on the following relationship:

$$
\text { percentage change in prices }=\% \text { change in wages }-\% \text { change in labor productivity. }{ }^{6}
$$

As long as the percentage change in wages does not exceed the percentage change in labor productivity, prices do not rise, while when wages grow less than labor productivity prices fall. When there is a wage-price spiral causing dramatic inflation like in the Polish case a very direct tool to cut the link between wage growth and inflation is to ensure that the right hand side of the equation is negative. The Polish reformers employed here rather harsh and potentially divisive policies by establishing very rigid norms. Enterprises were allowed to raise the wage bill by 30 percent of the increase in retail prices in January 1990, and by 20 percent thereafter. For the first three percent above these ceilings a marginal tax of 200 percent, for larger infractions a marginal tax of 500 percent had to be paid. The reason such harsh (low) "correction factors" and such high tax rates were applied had to with the fear that a restrictive monetary policy would not be enough to cut the link between inflation and wage growth in the Poland of 1989. As it turned out because corrective inflation was much larger than anticipated and the preconceived growth rates of credit expansion were not altered real money balances contracted more than foreseen and SOEs were in no position to grant large wage increases to their workers. So, in the first half of 1990 most firms were nowhere near the ceiling as far as permissible wage growth was concerned and hardly any SOE paid wage penalties. With monetary policy somewhat relaxed in the second half of 1990 the liquidity position of most SOEs improved and many of them reached the ceiling in November and December of that year. However, with the beginning of 1991 the collapse of CMEA trade and energy deliveries from the Soviet Union that had to be paid in hard currency caused a deterioration of the monetary balances of SOEs making it impossible to grant wage increases. The tax-based

\footnotetext{
${ }^{6}$ This equation can be derived if we assume that prices are a mark-up on wages: $\mathrm{P} *(\mathrm{Q} / \mathrm{L})=\gamma * \mathrm{~W}$, where $\gamma$ is a constant, $\mathrm{P}$ and $\mathrm{W}$ are prices and nominal wages respectively, while $\mathrm{Q} / \mathrm{L}$ is output per worker. Taking logs and the time derivatives and solving for $\mathrm{d} \log (\mathrm{P}) / \mathrm{dt}$ one gets the equation $\mathrm{d} \log (\mathrm{P}) / \mathrm{dt}=\mathrm{d} \log (\mathrm{W}) / \mathrm{dt}-[\mathrm{d} \log (\mathrm{Q}) / \mathrm{dt}-\mathrm{d} \log (\mathrm{L}) / \mathrm{dt}]$, which is the equation in the text.
} 
incomes policy was thus a rather blunt tool not contributing much to the decline of inflationary pressures.

The five elements of the stabilization program did stop a hyperinflation in Poland; it also brought down inflation to relatively tolerable levels but it did not eliminate it altogether. For several years there were inflationary expectations and pressures impacting on the price level. It took essentially a decade to get yearly inflation rates to levels prevailing in OECD countries. Still, overall this part of the reform program can be considered a success insofar as inflation was on a downward path without the danger to accelerate again and insofar as budget control could be regained. The stabilization program also included price liberalization and trade liberalization. Both liberalizations had been successful since nearly over night equilibrium in goods markets was established and shortages disappeared. Trade liberalization was the main channel through which competitive pressures on domestic producers were applied, more importantly it helped firms to redirect much of their trade to hard currency areas in a very short period of time.

The proposed concrete structural adjustment measures that foresaw rapid privatization of SOEs and a reform of the tax system within a short period of time were not very realistic at least as far as privatization was concerned. They were more a declaration of intent than a concrete action plan. Privatization of retail shops did occur rapidly, but the expansion of private sector employment was above all driven by what Schaffer (1993) calls "growth privatization." New private firms entering the market were responsible for job creation in a disproportionate fashion. For example, Konings, Lehmann and Schaffer (1996) show that in 1991 new private firms in the manufacturing sector were responsible for 20 percent of job creation even their employment share was only 4 percent. What Schaffer calls "privatization proper", that is the privatization of large enterprises was an extremely slow process, which led policy makers to rethink their privatization strategies. The law on large scale privatization in its final form still had to wait until April 1993 when it was passed by the Sejm.

The third pillar of the "big bang" reforms was the support by the Bretton Woods institutions and by the governments of the OECD countries. This support had two pillars. First, the IMF and OECD governments provided 2 billion stabilization fund provided in equal parts. Given the low level of foreign reserves, this stabilization fund was deemed necessary by the Polish government and the IMF to be able to defend the zloty against a speculative attack. With this large fund at its disposal the government was credible in its defense of the zloty and no speculative attack occurred. Thus the stabilization fund was never used. The second pillar was the write-off of part of Poland's external debt. The Polish government asked the IMF to facilitate negotiations with the aim to cancel 50 percent of the debt given by official creditors. In March 1991 a deal was struck between the Polish government and its official creditors to write off 50 percent of 30 billion US\$. A similar deal was struck later with the commercial creditors of Poland's remaining external debt of 13 billion US\$. These write-offs were of vital importance for the budget, since the resulting interest payments did not drive the deficit out of control. A 500 million US\$ structural adjustment loan provided by the World Bank was an important financial source for improvements in above all the infrastructure of state administration.

\section{IV.2 The reform program and the behavior of new private firms and SOEs}

The economic reforms initiated in January 1990 by the solidarity-led government had a clear macroeconomic focus intent on removing the large disequilibria in the economy and stopping hyperinflation. The reform program saw no need for microeconomic interventions at the firm level. Instead, the reform team had the conviction that the macroeconomic policies directly affecting 
SOEs, such as the slashing of subsidies, allowing bankruptcy and establishing positive real interest rates, would produce the right incentive structure for managers. At the same time it was thought that those who had been private entrepreneurs in the centrally planned economy and who were hindered whenever possible by the state bureaucracy to develop themselves would flourish once all the irrational constraints of central planning were lifted. It was also clear that transition to a market economy meant reallocation of labor on a large scale. If this reallocation was to be played out with a minimum of social tension then a social safety net providing income support for the temporarily unemployed had to be put in place with the launch of the reforms. We now turn to two of the actors and their behavior under transition starting off with new private firms.

The new private sector was by far the most dynamic in terms of job creation. Konings, Lehmann and Schaffer (1996) show in a regression framework that in 1991 new private firms had a far higher net employment growth rate than SOEs and privatized firms. Because of this higher capacity of job creation and because of large entry of new firms into the market once the reform program had eliminated all barriers to entry private sector employment soared. The success of new private firms had historical roots but was also tightly linked with the "shock therapy" applied in January 1990. In Poland private entrepreneurship was possible in the late years of the communist regime, when partial (market socialist) reforms of the centrally planned economy were introduced. ${ }^{7}$ Also the political conflicts in the early 1980s convinced many persons to seek their luck outside the state sector, and these persons learned being an entrepreneur in pre-reform times. However, under market socialism the private sector remained restrained by economic shortages, restrictions on trade and many government regulations. Once the macroeconomic measures of the "shock therapy" took a hold, the potential of these entrepreneurs was unleashed. In particular, liberalizing imports and establishing current account convertibility gave important impulses. The centrally planned economy had left many market niches empty, into which the new private entrepreneurs could now penetrate. The free flow of imports helped the development of wholesale and retail trade above all, but it also (with a lag) benefited manufacturing and services. Of course, not all private sector activities survived the liberalization (especially those did not survive which only took advantage of distortions in the centrally planned system) but the group of experienced entrepreneurs who had learned their trade under difficult conditions in the 1980s and the group of new entrants in 1990 were able to engage in profitable activities, successively filling out all the market niches that had been unoccupied in the centrally planned economy.

Because "privatization proper" stalled in 1990 and 1991, SOEs were still the main players with whom the government had to deal. For the reform program to really work it was important that sooner or later managers of SOEs started to adjust their behavior to the new macroeconomic environment (Pinto, Belka and Krajewski, 1993). Some of the SOEs chose to be commercialized which was conceived as a first step towards privatization. ${ }^{8}$ The main difference on paper between SOEs and commercialized enterprises was related to corporate governance. SOEs had a workers council which made all important personnel and investment decisions while in commercialized firms the workers council was abolished and replaced by a supervisory board, with four of its member nominated by the Ministry of Privatization and two by the employees. The de facto power in well-managed SOEs had, however, shifted to managers, which can be explained by the relative lack of managerial ability in Poland and the fear of rising unemployment. So, my discussion subsumes SOEs proper and commercialized SOEs under the term SOE.

\footnotetext{
${ }^{7}$ In Czechoslovakia and the GDR such private entrepreneurship was non-existent, in Czechoslovakaia because after the repression of the "Prague Spring" in 1968 no reforms to the economic system were undertaken, while in the GDR, being the "front state" of the Soviet camp, a rigid application of the Soviet model has always been pursued until 1985 when Gorbachev came to power and the Soviet Union started on perestroika.

${ }^{8}$ A commercialized SOE was put under the direct control of the Ministry and was supposed to be privatized within two years. Since in 1990 commercialized SOEs had tax advantages over SOEs many managers applied for commercialization. Once these tax advantages disappeared enthusiasm for commercialization dropped markedly.
} 
In the first year of the reforms there was relatively little adjustment as far as SOEs were concerned. With adjustment I mean a more efficient use of resources expressing itself in the shedding of redundant labor and in a cost-conscious use of inputs, the imposition of a hard budget constraint internally in the firm as well as "deep restructuring". Deep restructuring implies, for example, the search of new markets, the development of new product lines, the abandoning of unprofitable activities and the divestiture of social assets.

The reasons for the inertia observed in 1990 and the first half of 1991 were manifold. First, many SOEs had accounts in dollars and the large devaluation of the zloty in January 1990 raised the value of these accounts in the domestic currency. Second, until the middle of 1991 SOEs paid for their inputs imported from the Soviet Union with transfer rubles not with hard currency. So, their production was implicitly subsidized. Third, the commercial banking sector (essentially regional spin-offs from the National Bank of Poland) was not very well controlled and was willing to lend money to SOEs without evaluating the viability of firms. Fourth, the larger than expected corrective inflation reduced real wage costs dramatically. Fifth, well-performing SOEs were willing to grant inter-firm trade credit to SOEs performing badly. All these factors were, however, temporary and had fizzled out in the first half of 1991. Still the rigid macroeconomic framework imposed by the "shock therapy" did not force a change in behavior of many SOE managers because they expected the government to bail out their firms if they were in trouble like it had done in the past. One of the great achievements of the reform team was to never give in to mounting pressures from the side of managers and workers to loosen the no bailout policy. None of the first three governments ever budged on this issue. Eventually it dawned on SOE managers that there would be no help coming from the government and that they would have to rely on their own devices.

Pinto, Belka and Krajewski (1993) point to the heterogeneity of SOE performance. Within narrowly defined industrial sectors, some firms had engaged in "deep restructuring" and were profitable in the first two years of transition while others had not restructured and were financially in difficulty. This heterogeneity within sectors seems to imply that market forces had an impact on firms. Those with better initial conditions and with better managers had a superior performance. The imposition of a rational price system with import liberalization caused a larger jump in producer prices in heavy industry than in light industry. So, SOEs manufacturing heavy goods had been further away from world prices than SOEs manufacturing light goods. Hence, initial conditions were an important ingredient for the profitability of a production activity after reforms were implemented. Well performing SOEs were also in possession of abler managers regarding the marketing and selling of products. Since these SOEs also shed labor rather aggressively they improved productivity. In SOEs the remuneration of managers was not tied to profits but a multiple of the average wage in the firm. In spite of this lack of direct incentives many managers were strongly motivated and worked hard to improve the position of their firm. One reason for this was the expectation that they would gain during privatization by acquiring shares of the own firm at belowmarket prices. Equally important was their reputation to them. They felt that if they did a good job now, even if not properly remunerated for that, they would remain as directors after privatization had occurred or their good reputation would allow them to find a managerial job easily given the scarcity of managerial talent in Poland.

The upshot of these considerations is that the macroeconomic stabilization policies in conjunction with import liberalization eventually imposed a hard budget constraint and the rational use of resources, once SOE managers were convinced that no help would arrive from the state. In other words, initiating macroeconomic stabilization policies and sticking to their pre-determined goals despite immense social pressures in the end did change the microeconomic behavior of SOEs. The behavior by SOE managers also implied that changing the ownership structure of industry, while 
important in the medium run, was not that vital in the short-run. The growth of GDP that we see in 1992 is linked to the growth of production in industry. This growth occurred because of the entry and the expansion of new firms but also because many of the SOEs had improved their performance dramatically. It was this growth of GDP that convinced the Polish public to embrace further economic reforms. Rovelli and Zaiceva (2011) confirm this statement by showing within an OLS regression that Poland and the Czech Republic are the only two countries in the transition region where the average respondent in the European Barometer survey evaluates the economic changes in the 1990 s positively.

The most important of these further reforms that were enacted in the late 1990s are briefly discussed in the next section.

\section{The four reforms at the end of the 1990s}

\section{V.1 The health care reform of 1999}

This reform had above all three aspects. The first aspect is related to financing methods. Along the line of German "Krankenkassen", regional health insurance companies were set up and financed from a national health insurance surcharge. These health insurance companies then bought health services from doctors and hospitals. In addition, some financing for health services was provided by the state, in particular for highly specialized treatment like for example, heart surgery. As a third source of financing the reform foresaw private payment by patients for services not covered in the list of health insurance companies like for example plastic surgery. The second aspect concerned the decentralization of health administration having the decision making located at the province (powiat) level and not at the regional level (województwo level) as it was before. The intention of this decentralization was to bring health services closer to society since persons living in a province could now vote for the local authorities responsible for the decisions made about their health services. The third leg was the independence of all health care providers. This independence was particularly relevant in financial terms as the health providers could decide autonomously about their budgets and received legal status that made them independent from the regulations of budgetary law. The reform thus had good modernizing intentions trying to set the financing on a sounder footing, giving more autonomy to health care providers and increasing the involvement of local citizens in the running of the system. ${ }^{9}$

\section{V.2 The administrative reform of 1999}

This reform introduced three levels of state administration: the region (wojewódzstwo), the province (powiat) and the commune (gmina). The provinces had been abolished in 1975 under communism and were now reintroduced, while the 49 regions that existed before the reform where agglomerated into 16 . The reduction in the number of regions was intended to create economically more viable regions. At the same time within the new larger regions the self-administration bodies

\footnotetext{
${ }^{9}$ These good intentions did not all translate in good health services at the ground. This was maybe also due to the many modifications that the health reform was subject to. This large number of modifications have some researchers led to speak of a reversal of the 1999 health reform. This assessment goes probably too far, but if there is one reform that has not been adopted whole heartedly it is the health reform. At any rate, throughout the first decade of the new century there were loud complaints about poor health care, long waiting list, underpaid and overworked doctors and nurses. Consequently, the government under Donald Tusk enacted a new reform of the health care system in 2011, putting a large emphasis on a more privately run healthcare. It is too early to tell whether these reform efforts will improve Polish health care.
} 
received more power at the expense of the president of the region (the voivod). This shifting of power was meant to bring more democracy to the region. The same intent of a deeper penetration of democratic processes was behind the reemergence of the provinces. In summary, the administrative reform provided more efficient but also more democratic structures of state administration.

\section{V.3 The education reform of 1999}

Before the reform Poland had the following system of pre-tertiary education: a comprehensive primary school cycle lasting 8 years, a secondary school cycle with two tracks, namely a general track (lyceum) lasting 4 years, or a vocational track that could last 3 years (basic vocational school) or 5 years (secondary vocational school). This early tracking of pupils was considered undesirable by the reformers who established the following sequence of pre-tertiary education: a comprehensive primary school lasting 6 years, a comprehensive lower secondary school of 3 years (gymnasium) which was followed by a tracking decision to either an academic strand (general secondary school) or a vocational strand (secondary vocational school). The reformers expected a better average performance from Poland's pupils because of this delay in the tracking decision. In addition school curricula were modernized to make pupils fit for a knowledge-based economy.

Polish pupils of $9^{\text {th }}$ grade took part in the PISA tests of the OECD in 2000, 2003, 2006 and 2009. A comparison of the test scores of the 2000 and 2009 cohorts is particularly interesting since the first group was unaffected by the reforms while the second group had definitely only studied in reformed schools. The mean reading score in 2000 was with 479 below the OECD average while in 2009 it was 500, putting Poland above the OECD average (OECD, 2010a). While the share of high performers increased slightly, the improvement in the mean reading score was mainly brought about by a statistically significant fall from 23.2 percent in the share of low performers in 2000 to 15 percent in 2009, where low performers are defined as students with a proficiency level below $2 .{ }^{10}$ Thus in 2009, Poland found herself below the OECD average of 18.1 percent and had the ninth lowest share of low performers in the world, ranking 7 places before Hungary, the next best transition country, and 16 places above Italy who had around 21 percent of low performers in that year. In addition, between 2003, when only a minority had gone through the reformed schools and when mathematics was also assessed, and 2009 mathematics performance improved in Poland by 5 score points from 490 to 495 , getting closer to the OECD average of 499 score points.

These positive trends occurring between 2000 and 2009, i.e. after the reform was implemented, do not mean, of course, that we can pinpoint a causal effect of this reform on the performance of Polish pupils. The World Bank study by Jakubowski, Patrinos, Porta and Wiśniewski (2010) attempts to do this by matching students of 2006 PISA cohort with their counterparts of the 2000 cohort on their propensity score, i.e. their probability, to have entered vocational education as students did before the reform. The authors thus try to see whether those who would have entered vocational education under the old system benefitted from the fact that they remained one more year in general education. They show that this delayed entry into vocational education had a positive and

\footnotetext{
${ }^{10}$ Proficiency levels below 2 are levels $1 \mathrm{a}$ and $1 \mathrm{~b}$. We cite the description of tasks of these levels as they are given in OECD (2010b, p. 8):

"Tasks at [level 1a] require the reader to locate one or more independent pieces of explicitly stated information, to recognize the main theme or author's purpose in a text about a familiar topic, or to make a simple connection between information in the text and common, everyday knowledge. Typically the required information in the text is prominent and there is little, if any, competing information."

"Tasks at [level 1b] require the reader to locate a single piece of explicitly stated information in a prominent position in a short, syntactically simple text with a familiar context and text type, such as a narrative or a simple list. The text typically provides support to the reader, such as repetition of information, pictures or familiar symbols. There is minimal competing information. In tasks requiring interpretation, the reader may need to make simple connections between adjacent pieces of information."
} 
significant impact on student performance since the improvement was particularly large for this counterfactual group of entrants into vocational education. This evaluation study still does not catch the overall effect of the reform on average student performance, at best it can establish an impact of the reform on the sub-group of those switching later to vocational education. However, since the core of the reform was a delayed tracking decision, the reform seems to have caused at least partially the improvement in student performance via the channel of those entering vocational education later. At any rate, the encouraging results from this reform are not in doubt, making it probably the modernizing reform that has been most conducive to long-run growth.

\section{V.4 The pension reform of 1999}

In the 1990s Poland had a pension system that she had inherited from the communist past. Because of demographic trends but also because of special privileges to some groups of workers the pension system like in many countries had great financing difficulties that needed to be addressed. Chłon, Góra and Rutkowski (2000) estimate that in 2020 the pension system in its unreformed version would have generated an annual deficit of $4 \%$ of GDP, which would be unsustainable in the long run. So the old-age pension system was in urgent need to be reformed. Since the early 1990s there was a vivid debate about which way to reform the pension system. Eventually the conviction that a completely new system should be introduced prevailed and the solidarity-based Buzek government formulated a radical reform plan which was eventually adopted by parliament. It is noteworthy that predecessor governments, whose principal coalition partner were the post-communists, laid the groundwork for the reform. The "Act on the Social Security System" and the "Act on Pensions" became law on January $1^{\text {st }}, 1999$.

The new pension system was conceived as a multi-pillar system. The first pillar is still based on the pay as you go principle, while the second pillar is funded through investments. Both these pillars are mandatory for workers born in 1949 or later. A third funded pillar is voluntary. The two mandatory pillars are based on the defined contribution principle, that is benefits are linked to accumulated lifetime contributions and returns based on financial returns (second funded pillar) or the growth of the wage bill (first pillar). When the reform was enacted the social-security contribution rate for old age was 19.52 percent of the gross wage, paid in equal parts by the employee and the employer. The contributions are collected in a centralized fashion by the Social Institute of Security (ZUS) and then registered on individual accounts in both pillars. At the time of the enactment, two thirds of the contributions were dedicated to the first pillar and one third to the second pillar.

From the individual future pensioner's point of view the pension reform achieved two aims: first it provided actuarially fair pension benefits since these benefits were tightly linked to an individual's contribution, a state of affairs that was not present with the old pension system. Second it diversified risk since the first pillar is tied to developments in the labor market while the second and third pillars are tied to the capital market. The rate of return in the first pillar is linked to the growth rate of the covered wage bill while the rate of return in the second and third pillars are tied to the rate of return on investments. Empirical evidence shows that these two rates are not closely correlated so that paying contributions to the two types of pillars indeed implies diversification of risk. From the government's point of view the reform has created a sustainable system at lower levels of expenditure in terms of GDP than were spent before the reform took place. This sustainability of the new pension system was based on its future neutrality, that is on the fact that in the not too distant future the present value of benefits would equal the present value of contributions. 
Implementation of the new pension system meant an increase of the effective retirement age by around 5 years. In the 1990s average retirement age was approximately 55 for females and 59 for males. There existed a lot of pension privileges offering early retirement schemes, which were not touched by the reform. In the new system workers covered cannot retire before the nominal retirement age, which is 60 for females and 65 for males. Retiring early for those covered by the new pension regime is impossible both for legal and economic reasons. Pensions paid to early retirees would be extremely low since they are actuarially adjusted to the age of retirement. People were in general in favor of the new system, so they implicitly accepted the retirement age. These were rather young people, consequently they were little concerned about their own retirement. People born before 1949 were not affected by the changes and such left outside the discussion. Initially the savings were nil for the pension budget since older workers could legally retire early and did not bear the economic cost implied by the new system. Now, when the increase of the retirement age has become effective, the saving has become large, amounting to roughly 1 percent of GDP.

To avoid protests the pension reform law was accompanied by special rules for certain types of workers, which foresaw generous early retirement schemes. These schemes turned out to be expensive to the budget, but they were also politically difficult to eliminate. It took nearly ten years to solve this problem, when at the end of 2008 the law on bridging pensions was finally passed by the Sejm. The law eliminated nearly all types of bridging schemes allowing early retirement only in very special cases based on purely medical decisions. The number of potential cases thus dropped to roughly $1 / 10$ of the previously possible early retirement cases. Moreover, early retirement after the reform became conditional on earlier additional contributions paid by employers. The surviving bridging schemes also became limited to specific cohorts, covering only those workers who started working in special conditions before 1999. The law on bridging pensions is commonly considered the most important achievement of the first Tusk government in the legislative term of 2007-2011. ${ }^{11}$

The four reforms that I have briefly described here were a set of modernizing reforms that were urgently required to keep the country on a strong growth path. Some of the flaws of the initial reform acts were later ironed out by the first Tusk government. The four big reforms were implemented and enacted during the tenure of a reform-friendly government, which had its roots in the Solidarity movement. One needs, however, also do justice to those governments, which I call reform-neutral, since under their stewardships the ground was often laid for the legislative acts pushed through by successor governments that were reform-friendly. For example, the pension reform was lively debated in the three left-wing governments preceding the Buzek government. Without this prior discussion it would have been difficult to pass the reform in the end. In my opinion, the continuity of economic reform ideas, which straddled the political divide and which resulted in reform legislation on a broad front and its fine-tuning over time, is the main factor explaining the astonishing growth performance of the Polish economy.

\section{The Polish labor market: reforms and problems}

As I touched upon in the introduction, if there is one area where we cannot really speak of a good performance, it is the labor market; this statement at least holds until the aftermath of EU accession when the unemployment rate came down and employment rose rapidly (see figures 3 and 4). The main long-term challenge that Polish policy makers faced regarding the labor market was linked to

\footnotetext{
${ }^{11}$ A serious setback regarding the pension reform occurred when personnel of the security services (army, police, etc.) were taken out of the new system in 2002; the same happened to miners in 2005. Both groups were originally included in 1999. The second Tusk government is now trying to reverse these costly modifications, but this is a politically delicate and not easy task.
} 
becoming a full member of the EU. Accession to the European Union has generated opportunities and challenges for Poland as far as the labor market is concerned. When prospects are certain that a country will join the EU, FDI flows become continuous and solid, creating jobs in the labor market of the country that accedes. This job creation will be more pronounced the better the skill profile of the workforce of the joining country is. Being part of an internal market permits free movement of labor in principle often easing the demographic pressures on the domestic labor market. Outward migration might, however, also result in "brain drain" depriving a new member state (NMS) of those sections of the workforce that are especially vital for productivity growth. However, the main challenge of EU membership consists in ensuring that the labor market becomes competitive in a broad sense. If we think about being competitive from the labor demand side, this implies that labor market institutions, regulations in general and the tax system all need to be shaped in such a way as to boost the willingness of firms to create jobs. When we focus on the supply side, reforms need to have at least a two-fold thrust to ensure that the workforce in the new member state is competitive with workers elsewhere in the union. First, skill levels of workers need to be developed in tune with the demand of domestic but also of multinational firms if a country wants to claim a decent place in the international production chain. Second, the social benefit system has to be structured in such a way as to target those who really need help and, at the same time, ensure that the incentives are pushing workers to prefer work over unemployment or inactivity.

Changing the behavior of workers and firms is a long-term process and Poland, like most of the NMS, has spent nearly a decade before accession to the EU to improve the performance of her labor market by reforming her institutions. Poland had to manage the reforms in the labor market in such a way that they ensured a transition as smooth as possible from an economy closed to world markets to one integrated in world markets (and in particular in EU markets). As we can see from figures 3 and 4 accession seemed to have given a boost to employment and to have lowered unemployment in Poland, but this boost only occurred because Poland has been successful, at least partially, in restructuring her economy and in reallocating labor from declining to expanding firms and sectors increasing labor productivity in a genuine fashion and not just by labor shedding (Rutkowski, 2007). We should also note that the years following accession were years of a booming world economy. It is, therefore, very difficult to disentangle the causal effect of accession on employment growth.

\section{VI.1 The structure of labor market states and their trends}

We shall look at participation, employment and unemployment rates as well as the incidence of long-term unemployment in Poland ${ }^{12}$ comparing the Polish numbers to EU-15 averages. We use four data points (1998, 2001, 2004 and 2007) in our analysis and disaggregate these data by gender, education and age and thus go behind the aggregates of figures 3 and 4 .

The participation rates in Poland are lower than in EU-15. This comes about because of lower rates of the young (15-24) and of older workers (55-64). The young in Poland in the period 1998-2007 had a relatively constant participation rate of 10 percent compared to an average rate of 35 percent in EU-15, while the number for the older workers are 32 percent and 49 percent respectively. The difference in the participation rate is particularly striking for persons with lower education

\footnotetext{
${ }^{12}$ The Working Age Population - WAP - (on paper, women: 15-60 years of age, men: 15-65 years of age) can be decomposed in three states: employment (E), unemployment (U) and inactivity (I). The labor force (LF) equals the sum of those who have a job plus those who do want to have a job but do not have one and search for one: $L F=E+U$. The participation rate is then LF/WAP, the employment rate E/LF, and the unemployment rate U/L. Long-term unemployment (LTU) is defined as those workers with a continuous unemployment spell of more than a year. The incidence of long-term unemployment is the share of the long-term unemployed in total unemployment: LTU/U.
} 
attainment (pre-primary, primary and lower secondary), falling in the Polish case from 38 percent to 29 percent between 1998 and 2007 and rising in the EU-15 case from 55 percent to 59 percent in the same period. The particularly low activity rate of the young could be caused by several developments: more involvement of young workers in the informal sector, the unwillingness of the low skilled young to enter the labor market at all, longer spells in full-time education or relatively few opportunities of part-time employment. Many older workers with low educational attainment find it particularly difficult to adjust to the new conditions, thus they might become "discouraged workers" and withdraw from the labor market.

The overall employment rate in Poland fell continuously from about 75 percent in 1989 to 55 percent in 2003 (figure 3). This strong downward trend is tightly linked to the aggressive labor shedding that took place in this period. In the aftermath of the 1998 crisis in Russia we see a particularly large "shake-out" of unproductive labor taking place in enterprises. That it is a "shakeout" of low productivity labor can be inferred by the strong rise of the average real wage in 1999, the year after the Russian crisis (figure 2). With accession the employment rate rose continuously until the world financial crisis stopped this upward trend. The low employment rates for Poland that we see in figure 3 are in particular driven by lower rates for older workers and less educated workers. For older workers they are about 10 percentage lower than in EU-15, where they reach about 40 percent. Workers with less education are much less employed in Poland, and in all other NMS for that matter, than in EU-15. Their employment rates in Poland were around 30 percent throughout the period, roughly 20 percentage points lower than in EU-15.

The unemployment rates were much higher in Poland than in other CEE economies and in EU-15 in most years of the reported period. Slicing the data by gender we see no discernible difference. The fall in the unemployment rate that accelerated in the years after accession can be explained by outward migration but also by large increases in hiring. The incidence of Polish long-term unemployment was around 50 percent since the late nineties and about 10 percentage points higher than in EU-15, pointing to the great difficulties of the unemployed to flow out of this state.

In summary, the least skilled among young and older withdraw from the labor market to a much larger degree than this happens in the EU-15. This withdrawal can be explained by the inability or the unwillingness of these workers to adapt to the new labor market conditions during the transition process. Those older workers and workers with low education who remain in the labor market find less employment opportunities than their counterparts in the old member states. The age group most affected by unemployment is the young like in the EU-15, the youth unemployment rates are, however, substantially higher in Poland. Successive Polish government promoted active measures for the young to fight this high youth unemployment. A rigorous evaluation of these schemes has to my knowledge not been undertaken. Finally, long-term unemployment is more severe in Poland. How Polish policy makers dealt with older workers and less educated workers as "problem groups" we shall see below.

\section{VI.2 Labor Market Institutions and Labor Market Reforms in Poland}

Students of the labor markets in the NMS often have opposing views on how flexible these markets have become. While Boeri and Garibaldi (2006) state that labor markets institutions in the NMS point to relative flexibility, Rutkowski (2007) maintains that their labor markets have still been rigid in the first decade of the new century. These contradictory assessments come about because the authors use different benchmarks for comparison. Boeri and Garibaldi compare the institutions of the NMS labor markets with those of EU-15, while Rutkowski pursues the idea that the only viable benchmark should be the labor market institutions of the Anglo-Saxon countries. In my opinion this 
preference of the latter author is more based on ideology than facts since if we take a longer-term view the superior performance of the very flexible Anglo-Saxon labor markets is not certain. In addition, labor legislation that is relevant for accession states has to be seen embedded in the EU social charter and in EU policies of social protection and inclusion. Consequently, it seems more plausible to compare labor market institutions of the NMS impacting on flexibility with institutions as they are prevalent in the EU-15. A sensible way to analyze the reform of labor market institutions is to divide the assessment into factors that predominantly impact on labor demand and into factors that mainly influence labor supply.

As far as labor demand is concerned we look at three factors: employment protection legislation (EPL), the role of unions in collective bargaining and taxes on labor. The EPL overall index developed by OECD researchers is a weighted composite index made up of three separate indices, the indices for regular contracts, for temporary contracts and for collective dismissals. The index for regular contracts in Poland is slightly lower than for EU-15, while the index for temporary employment is substantially lower in Poland. The one index where the Polish index is larger than the EU-15 index relates to collective dismissals. Since temporary employment in Poland amounts to roughly a quarter of all employment and since collective dismissals were rare, on the measure of EPL the Polish labor market exhibits more flexibility than the labor markets of EU-15. Important statistics for collective bargaining are union density and union coverage: both these statistics are much lower in Poland than in EU-15; union density in 2006 was 16 percent in Poland and about 39 percent in EU-15. Essentially in Poland, we see a near collapse of the influence of trade unions in the Polish economy, a development not necessarily beneficial. ${ }^{13}$ Union coverage, that is the fraction of workers to whom a collective agreement applies, is much lower in Poland (35 percent in 2006) than in EU-15 (81 percent in 2006). So, also on this measure the Polish labor market seems much more flexible than the labor markets of EU-15. Finally, the implicit tax rate ${ }^{14}$ on labor is somewhat lower in Poland than in EU-15. In summary, from a demand perspective, institutional reforms have made the Polish labor market more flexible than the labor markets in the old member states.

Turning to the factors that influence labor supply we look at three factors: unemployment benefits, non-employment benefits like early retirement schemes and disability pensions, as well as the evolution of wage inequality from early to late transition.

In Poland the unemployment benefit system has undergone dramatic changes over the 1990's. With rising unemployment, these changes were often dictated by budget considerations. However, as policy makers became aware of the disincentive effects of a too generous unemployment benefit system, changes in legislation also reflected attempts to increase the willingness of the unemployed to increase search and take on jobs. At the beginning of transition, Polish unemployment benefits were earnings related, open ended and without a previous work requirement, causing a flooding of offices of the Public Employment Services by applicants for benefits. Within a year, unemployment insurance benefits were limited to one year and a previous work requirement was imposed. By December 1994 earnings related benefits were eliminated and a flat rate amounting to

\footnotetext{
${ }^{13}$ The idea that the main impact of trade unions is the "destruction of jobs" in a firm, sector or the economy, is not shared by all students of trade unions. Applying Albert Hirshman's concept of "exit" and "voice" to trade unions, some economists maintain that trade unions can give "voice" to workers' concerns about inefficiencies that they observe regarding production and organization in a firm; as a consequence the existence of trade unions might actually increase the efficiency in the labor market. Other researchers have pointed to the large transactions costs that arise in the case of bargaining at the individual level in large firms. Trade unions can clearly reduce these transaction costs.

${ }^{14}$ The implicit tax rate on employed labor is defined as the sum of all direct and indirect taxes and employees' and employers' social contributions levied on employed labor income divided by the total compensation of employees working in the economic territory increased by taxes on wage bill and payroll.
} 
$36 \%$ of the average wage was introduced. ${ }^{15}$ Thus within a few years, major aspects of the unemployment benefit system were overhauled by the Polish government with an eye on both reducing budgetary pressures as well as increasing the search effectiveness of the unemployed. Relative to EU-15 the level of unemployment benefits has become not very generous; especially for the long-term unemployed income support is very limited and since it is provided by cash-starved municipalities often only on paper. So, clearly the Polish unemployment benefit system as it is now should create few disincentive effects to search for work.

As we have seen, activity and employment rates of older and less skilled workers have been low from the early nineties until 2007. Polish policy makers strongly contributed to the withdrawal of older workers by introducing an array of measures that spurred these workers on to retire long before the statutory retirement age. Throughout the nineties invalidity and disability pensions were the main income support measure for these workers. Comparisons with OECD countries show that while the fraction of workers with impaired ability to work ${ }^{16}$ was roughly the same in Poland and other OECD countries in the 1990's, Poland, in 1999, had 182 persons in 1000 who received an invalidity pension in the age bracket 45-54, while the average in the OECD was 73 persons in 1000. The pension reform enacted in 1999 reduced the inflow of new disability pension claimants. With an economy deteriorating in 1999, this reduced inflow was completely compensated by an increased inflow of early retirees. The majority of these early retirees have been unemployed workers who were still in working age. Thus increasing expenditures on the early retirement of unemployed workers was a consciously chosen policy to "deactivate" a substantial part of the unemployed. For example, in the years 2003-2004, 40\% of unemployed between the ages of 55-64 were given early retirement packages, while for the age groups 45-54 and 15-44 the percentages were 19\% and 11\% respectively. Since early retirement schemes were considered passive labor market policy measures, these pensions were paid out of the Labor Fund (LF). While in $19976.4 \%$ of LF expenditures were destined for early retirement pensions, in 1999 this share was already 20.3\%, reaching $47.2 \%$ in 2004. Thus, the increase in expenditures on early retirement pensions did not only push older Polish workers out of the labor force, it also crowded out expenditures on active labor market policies. Only the discussed reforms of the Tusk government in 2008 have nearly entirely eliminated these bridging schemes.

By providing strong income support for older workers intent on withdrawing from the labor market Polish governments clearly encouraged such behavior. In times of a sustained up-turn, some of these workers might have been in demand. A too generous early retirement policy might, therefore, in some sense "overshoot" the target of downsizing the workforce and be very inefficient in the medium run. On the other hand, as already stated, from a political and social point of view this large downsizing of the workforce in times of prolonged and large-scale labor shedding might be the only way to ensure enough social cohesion. So, the "deactivation" of older workers or workers who are unwilling to adjust to the new labor market conditions generated a major trade-off for Polish policy makers. On the one hand, "deactivation" is required in times of large excess supply of labor to avoid social turmoil. On the other hand, "deactivation" is difficult to reverse in times of excess labor demand, which occurred in the years 2004-2007 when the world economy boomed. To find the right level of "deactivated" workers and avoid overshooting this level is a difficult task that Polish policy makers did not resolve satisfactorily.

The success of the educational reform can also be established by looking how it impacts on the distribution of wages. Under central planning the wage distribution in Poland was compressed

\footnotetext{
${ }^{15}$ Those without previous employment were entitled to benefits close to the minimum wage!

${ }^{16}$ Having impaired ability to work does not mean, of course, that persons with such an affliction are completely unable to work.
} 
reflecting low returns to education. In table 2 we can see the evolution of the distribution of wages for Poland and compare this evolution to the wage structures in France and the United States. For Poland, we see a steep increase in the ratio of the $9^{\text {th }}$ to the $1^{\text {st }}$ decile, and a relative mild increase in the ratio of the median to the $1^{\text {st }}$ decile between 1992 and 2006. It is striking that over the same period the median worker gains relatively little to the worker in the first decile. In other words, the large rise in inequality is mainly caused by gains in the upper part of the distribution, i.e. because highly skilled workers are compensated for the acquisition of skills. What is also striking is the rise in the incidence of low pay to roughly one quarter of all employed by the year 2004. Poland thus reaches the same low pay incidence as exhibit the United States, one of the OECD countries with the highest fraction of low pay workers. The United States also has one of the most flexible labor markets in the developed world with a relatively unequal distribution of earnings during the 1990's and in the new century. At the time of accession, Poland has a slightly less unequal distribution than the United States. Strikingly, France shows the most equal distribution of earnings among the three countries with far lower ratios of the median to the $1^{\text {st }}$ decile and of the $9^{\text {th }}$ to the $1^{\text {st }}$ decile. Thus, the evolution of the earnings distribution allows us to draw the conclusion that in late transition Poland had wages that seem to be correlated with the relative scarcity of labor skills and that as far as the structure of remuneration is concerned the Polish labor market is closer to the labor market of the U.S. than to other continental European labor markets.

In summary, from the demand side the Polish labor market has become more flexible than the EU15 labor markets. Looking at factors impacting on the supply, the unemployment benefit system has become non-generous and has eliminated the disincentives to search for a job. At the same time for nearly two decades there existed large scale bridging schemes that "deactivated" older and lowskilled workers. Well educated workers can command relatively high wages while there is a large section of the workforce employed in low paid jobs. Compared to most continental European labor markets the Polish labor market has thus become very flexible and responsive to the needs of Polish firms, which via a tortuous and long way of shedding unproductive labor and of restructuring have become competitive in world and EU markets.

\section{Conclusions}

The impressive growth performance of the Polish economy since 1992 is intimately related to the persistence of reform efforts by successive Polish governments over two decades. These reform efforts occurred despite a relative fractured and unstable political landscape in the 1990s. Large reform packages were implemented by the Mazowiecki government at the beginning of the transition to a market economy and by the Buzek government at the turn of the $21^{\text {st }}$ century. Both these government were located at the right and center of the political spectrum as were the other governments that implemented important reforms. The success of the reforms was possible because of a virtuous cycle: right-center governments adopted reforms, which imposed costs in the short-run to large sections of the population. As a consequence, the right-center governments were voted out of office and left leaning governments took over. However, these left leaning governments did not reverse any of the reforms of their predecessors thus ensuring that the reforms could produce positive effects that inclined a majority of Poles to vote for a right-center coalition in the next voting cycle, i.e. for a reform-friendly government. Among policy makers responsible for economic issues there existed a broad consensus about the general reform path that Poland had to take independent of party affiliation. So, while left leaning governments did not enact major reform projects they did prepare the enactment by leading the discussion of reforms projects in the public and in the legislative bodies.

Painting with a broad brush, we have three large blocks of reforms occurring in the two decades since the communists relinquished power. We have the large block of reforms of the Mazowiecki 
government, spearheaded by the group of economists around Leszek Balcerowicz, which stabilized the economy and put it on its path to a market oriented economy. The second block are the large modernizing reforms of the Buzek government, while the first Tusk government fine-tuned some of these earlier reforms. Of course, other governments also enacted reforms, individually of lesser importance, but their sum contributing to the modernization of the Polish economy to the same degree.

The modernization of the Polish economy involved the restructuring of SOEs and privatized firms implying large labor shedding and the "shake-out" of workers unproductive in the new demand constrained economic environment. This tortuous and prolonged process released many persons who had great difficulties in finding re-employment, above all older and less skilled workers. Successive Polish governments were not able to re-integrate these workers into employment, and chose to "deactivate" a large fraction of them by granting them relatively generous disability or early retirement pensions. So, when one hails the great growth performance of the Polish economy and the implementation of a consistent reform agenda by Polish policy makers as its underlying cause, one should not ignore that for more than a decade a substantial fraction of the Polish workforce did not actively participate in the economic life of the country. 


\section{References}

Boeri, T. and Garibaldi, P., 2006. Are labour markets in the new member states sufficiently flexible for EMU? Journal of Banking \& Finance, 30 (5), pp. 1393-1407.

Chłon, A., Góra, M. and Rutkowski, M, 2000. Shaping pension reform in Poland: security through diversity. World Bank Primer, Washington D.C.

Eamets, R., 2011. Restricted macroeconomic policy and a flexible labor market. Unprocessed manuscript, Tartù, Estonia.

Gomułka, S., 1992. Polish economic reform, 1990-91: principles, policies and outcomes. Cambridge Journal of Economics, 16 (3), pp. 355-372.

Government of Poland, 1989. Memorandum on the economic reform program in Poland and the role of foreign financial assistance. Warsaw, September 23.

Hayek, F., 1945. The use of knowledge in society. American Economic Review, 35 (4), pp. 519-530.

M. Jakubowski, M., Patrinos, H.A., Porta, E. and Wiśniewski, J., 2010. The Impact of the 1999 Education Reform in Poland. World Bank Policy Research Working Paper No. 5263, Washington D.C.

Konings, J., Lehmann, H. and Schaffer, M.E., 1996. Job creation and job destruction in a transition economy: ownership, firm size, and gross job flows in Polish manufacturing 1988-91. Labour Economics, 3, pp. 299-317.

Kornai, J., 1986. The Hungarian reform process: visions, hopes, reality. Journal of Economic Literature, 24 (4), pp. 1687-1737.

Organization for Cooperation and Development, 2010a. PISA 2009 results: learning trends: changes in student performance since 2000 (Volume V). OECD, Paris.

Organization for Cooperation and Development, 2010b. PISA 2009 at a glance. OECD, Paris.

Pinto, B., Belka, M. and Krajewski, S., 1993. Transforming state enterprises in Poland: evidence on adjustment by manufacturing firms. Brookings Papers on Economic Activity, 1993 (1), pp.213-270.

Roland, G., 2002. The political economy of transition. Journal of Economic Perspectives, 16 (1), pp. 29-50.

Rovelli, R. and Zaiceva, A., 2011. Individual support for economic and political changes: evidence from transition countries, 1991-2004. Unprocessed manuscript, Bologna and Modena.

Rutkowski, J., 2007. From the shortage of jobs to the shortage of skilled workers: labor markets in the EU new member states. IZA Discussion Paper No. 3202, Institute of the Study of Labor, Bonn, Germany.

Schaffer, M.E., 1993. Polish economic transformation: from recession to recovery and the challenges ahead. Centre for Economic Performance Working Paper No. 446, London School of Economics. 


\section{FIGURES}

Macroeconomic indicators of transition countries, old member states of European Union and the United States

\section{Figure 1. GDP dynamics in Poland, CEE; CIS, EU-15, and US}

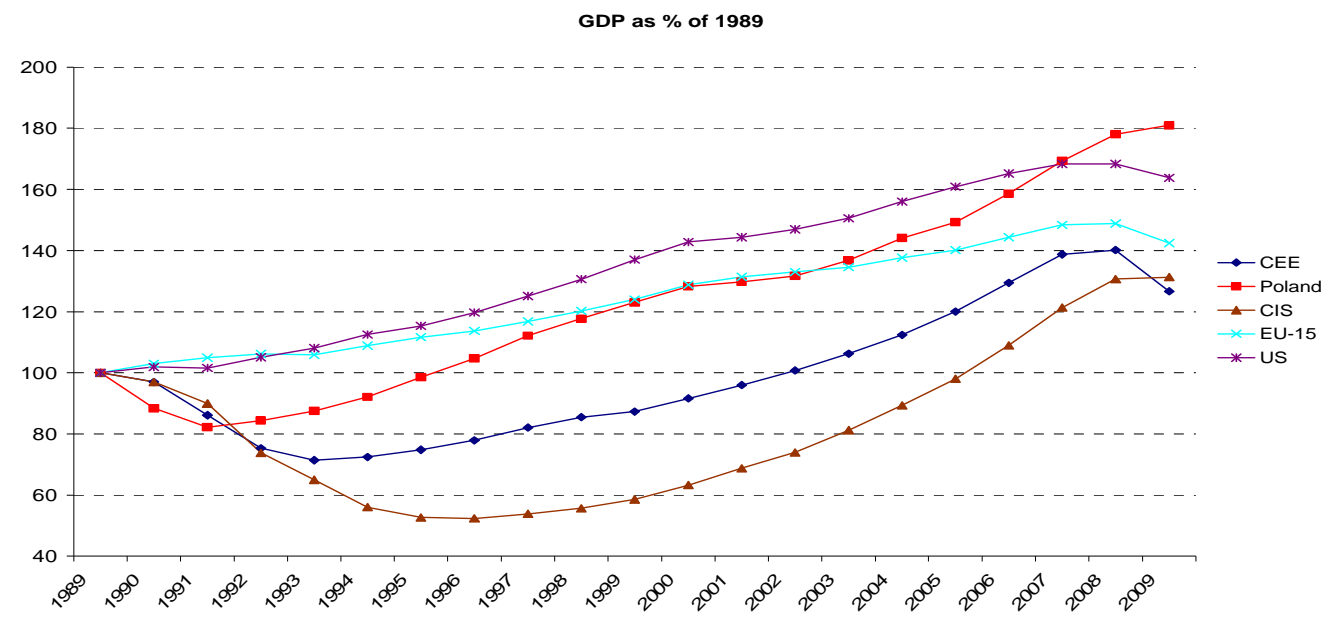

Notes: Unweighted averages for CEE; CIS and EU-15. The data are taken from EBRD and OECD databases. $\mathrm{CEE}=$ Central and Eastern Europe; CIS=Commonwealth of Independent States; EU-15=15 old member states of European Union, US=United States.

Figure 2. Poland - Dynamics of labor productivity and real wages (as \% of 1989)

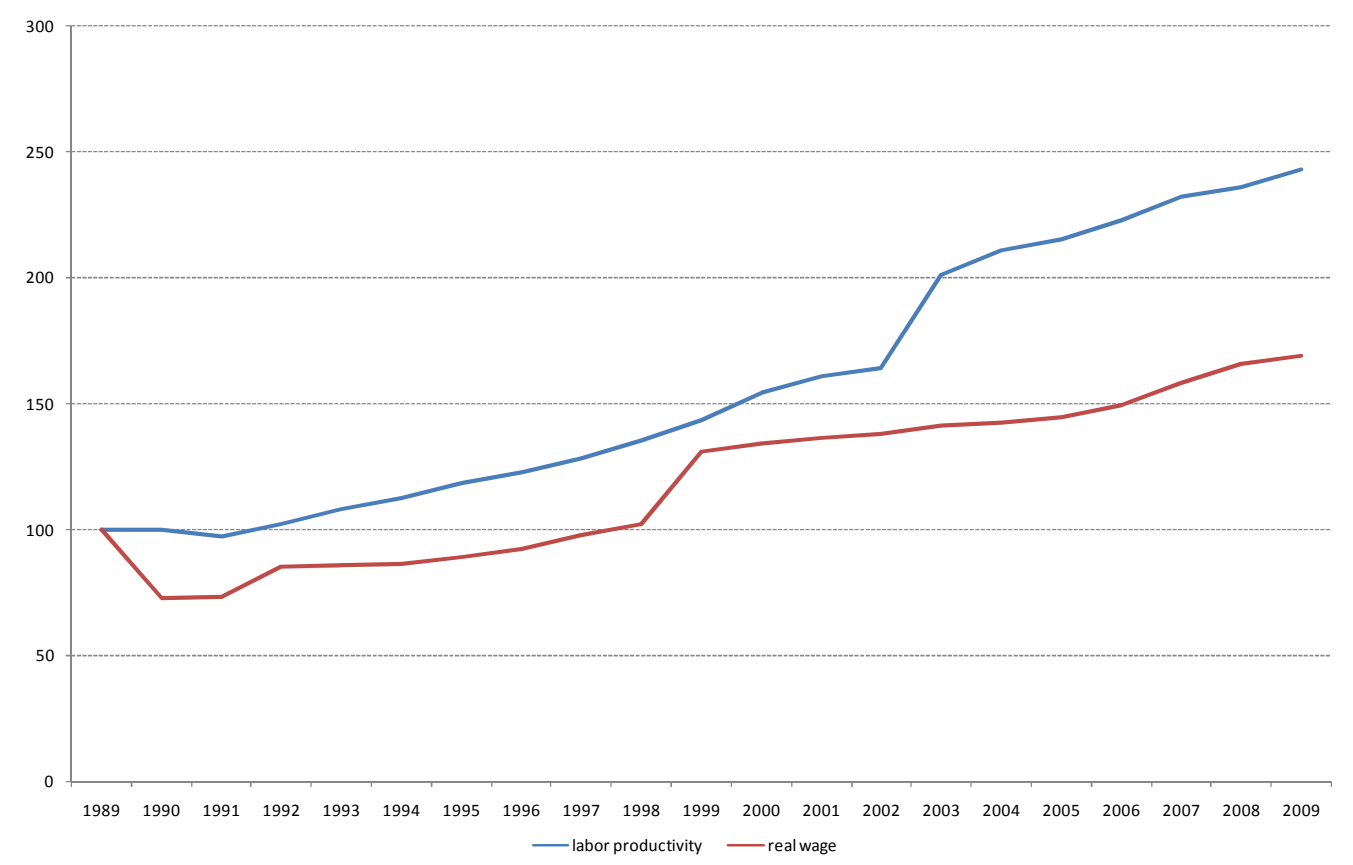

Sources: Polish Statistical Office, IMF and World Economic Outlook Database Notes: Labor productivity=GDP (in 2000 prices)/employment (end of year);

Real wages (in 2000 prices). 
Figure 3. Employment-to-population ratios in Poland, CEE, CIS, EU-15, and US.

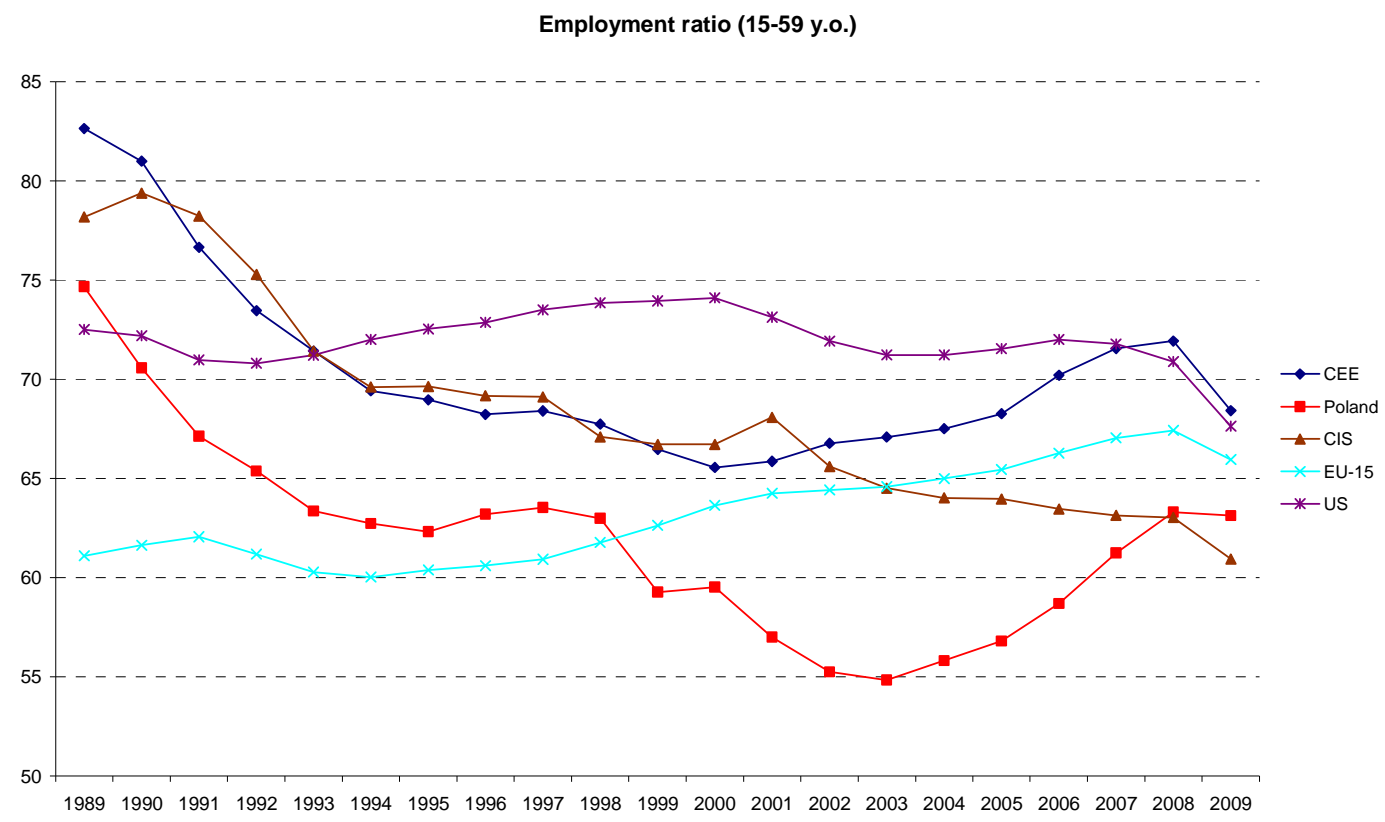

Notes: 15-64 for EU-15 and 16-64 for US. Unweighted averages for TEs and EU-15. The data are taken from TRANSMONEE and OECD databases.

Figure 4. Unemployment rates in Poland, CEE; CIS, EU-15, and US.

LFS unemployment rate

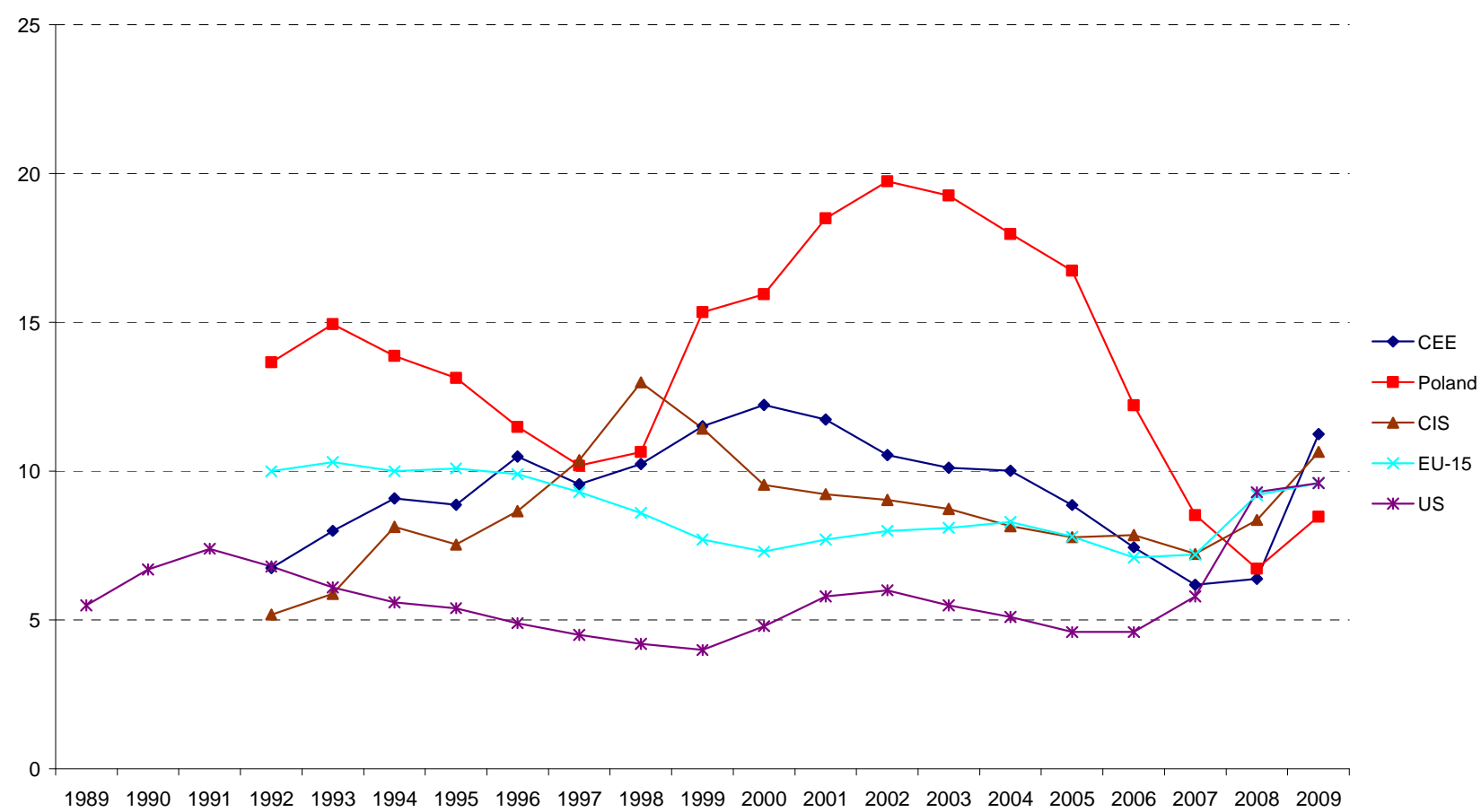

Notes: Unweighted averages for TEs and EU-15. The data are taken from TRANSMONEE and OECD databases. 
Figure 5. A supply constrained Economy and Corrective Inflation

\section{Price level}

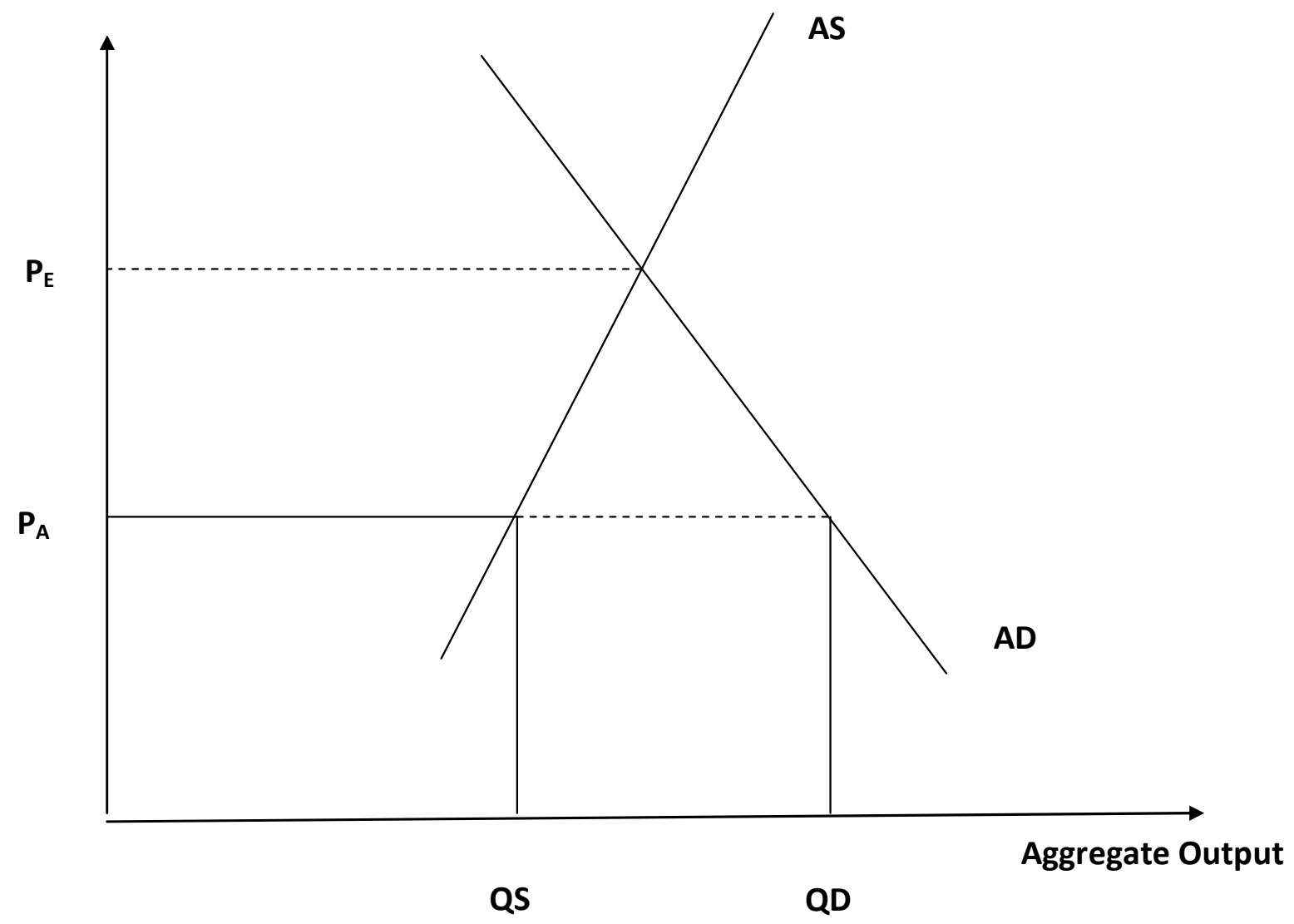

$Q D\left(P_{A}\right)-Q S\left(P_{A}\right)=$ Excess Demand at Administered Price level

$P_{E}-P_{A}=$ Change in Price Level after Price Liberalization = Corrective Inflation brought on by Price Liberalization 
Figure 6. Taxonomy of Economic Reform in a Transition Context - The Time Dimension

Price liberalization

Trade liberalization

Macroeconomic stabilization

Privatization

Social safety net and income support for the unemployed

Tax reform

Creation of a decentralized private banking system and

financial sector

Pension reform

Educational reform

Systemic reforms:

Reforming the labor market

Generating a business-friendly environment that also

encourages competition

Generating a commercial law structure

Generating a civil code 
Table 1. Polish governments and their most important legislation regarding the economic sphere

\begin{tabular}{|c|c|c|c|c|c|}
\hline \multirow{2}{*}{$\begin{array}{l}\text { Government } \\
\text { (Name of prime } \\
\text { minister) }\end{array}$} & \multirow{2}{*}{ Reform and description } & \multirow{2}{*}{ Act: name and short description } & \multicolumn{3}{|c|}{ Act } \\
\hline & & & passed on & announced & $\begin{array}{c}\text { took effect } \\
\text { on }\end{array}$ \\
\hline \multirow[t]{8}{*}{ TadeuszMazowiecki } & \multicolumn{2}{|c|}{$\begin{array}{l}\text { Balcerowicz Plan } \\
\text { The preparations of the Plan started in September 1989. It consisted of } 10 \text { Acts, which were passed and } \\
\text { signed in December. }\end{array}$} & & & \\
\hline & $\begin{array}{l}\text { The Act abolished the principle under which, } \\
\text { unprofitable state-owned companies were financed } \\
\text { from budget and allowed state-owned companies to } \\
\text { declare bankruptcy. }\end{array}$ & $\begin{array}{l}\text { Act on Financial Economy of State-owned Companies } \\
\text { (Ustawa z dnia } 27 \text { grudnia } 1989 \text { r. o zmianie w } \\
\text { Ustawie o Gospodarce Finansowej Przedsiębiorstw } \\
\text { Państwowych), (Dz. U. } 1989 \mathrm{nr} 74, \text { poz 437) }\end{array}$ & 27.12 .1989 & 30.12 .1989 & 01.01 .1990 \\
\hline & $\begin{array}{l}\text { The Act prohibited the central bank to finance the } \\
\text { budget deficit and issue unlimited amount of } \\
\text { money. }\end{array}$ & $\begin{array}{l}\text { Act on Bank law and National Bank of Poland } \\
\text { (Ustawa z dnia } 28 \text { grudnia } 1989 \text { r. o zmianie ustaw } \\
\text { Prawo bankowe i o Narodowym Banku Polskim), (Dz. } \\
\text { U. } 1989 \mathrm{nr} 74 \text {, poz. } 439 \mathrm{z} \text { dn. } 30.12 .1989 \text { ) }\end{array}$ & 28.12 .1989 & 30.12 .1989 & 01.01 .1990 \\
\hline & $\begin{array}{l}\text { The Act abolished preferential loans for state- } \\
\text { owned companies and tied interest rates to inflation } \\
\text { rates. }\end{array}$ & $\begin{array}{l}\text { Act on Credits (Ustawa z dnia } 28 \text { grudnia } 1989 \text { r. o } \\
\text { uporządkowaniu stosunków kredytowych), (Dz. U. } \\
1989, \mathrm{nr} 74 \text {, poz. 440) }\end{array}$ & 28.12 .1989 & 30.12 .1989 & 01.01 .1990 \\
\hline & $\begin{array}{l}\text { The Act introduced tax on extensive wage growth } \\
\text { (so called popiwek). }\end{array}$ & $\begin{array}{l}\text { Act on Taxation of Excessive Wage Growth (Ustawa z } \\
\text { dnia } 27 \text { grudnia } 1989 \text { r. o opodatkowaniu wzrostu } \\
\text { wynagrodzeń w } 1990 \text { roku, (Dz. U. 1989, nr 74, poz. } \\
438 \text { z dn. 30.12.1989) }\end{array}$ & 27.12 .1989 & 30.12 .1989 & 01.01 .1990 \\
\hline & $\begin{array}{l}\text { The Act uniformed tax rule for all sectors of the } \\
\text { economy. }\end{array}$ & $\begin{array}{l}\text { Act on the New Rules of Taxation (Ustawa z dnia } 28 \\
\text { grudnia } 1989 \text { r. o zmianie niektórych ustaw } \\
\text { regulujących zasady opodatkowania), (Dz. U. 1989, nr } \\
74 \text {, poz. } 443 \mathrm{z} \text { dn. } 30.12 .1990 \text { ) }\end{array}$ & 28.12 .1989 & 30.12 .1989 & 01.01 .1990 \\
\hline & $\begin{array}{l}\text { The Act allowed companies with foreign capital to } \\
\text { repatriate their profits and exempted them from } \\
\text { paying the tax levied on extensive wage growth. } \\
\text { The Act obligated those enterprises to sell foreign } \\
\text { currencies to the state. The exchange rate was set by } \\
\text { the central bank. }\end{array}$ & $\begin{array}{l}\text { Act of Economic Activity of Foreign Investors } \\
\text { (Ustawa z dnia } 28 \text { grudnia } 1989 \text { r. o zmianie ustawy o } \\
\text { zasadach prowadzenia na terytorium Polskiej } \\
\text { Rzeczypospolitej Ludowej działalności gospodarczej } \\
\text { w zakresie drobnej wytwórczości przez zagraniczne } \\
\text { osoby prawne i fizyczne oraz ustawy o działalności } \\
\text { gospodarczej z udziałem podmiotów zagranicznych.), } \\
\text { (Dz. U. 1989, nr 74, poz. } 442 \text { z dnia 30.12.1989). }\end{array}$ & 28.12 .1989 & 30.12 .1989 & 01.01 .1990 \\
\hline & $\begin{array}{l}\text { The Act introduced internal convertibility of the } \\
\text { złoty, abolished the state monopoly in international } \\
\text { trade and obligated companies to sell foreign } \\
\text { currencies to the state. }\end{array}$ & $\begin{array}{l}\text { Act on Foreign Currency (Ustawa z dnia } 28 \text { grudnia } \\
1989 \text { r. o zmianie ustawy - Prawo dewizowe), (Dz. U. } \\
\text { 1989, nr 74, poz. } 441 \text { z dnia } 30.12 .1989 \text { ) }\end{array}$ & 28.12 .1989 & 30.12 .1989 & 01.01 .1990 \\
\hline
\end{tabular}




\begin{tabular}{|c|c|c|c|c|c|}
\hline & $\begin{array}{l}\text { The Act introduced the same customs law for every } \\
\text { business entity. }\end{array}$ & $\begin{array}{l}\text { Act on Customs Law (Ustawa z dnia } 28 \text { grudnia } 1989 \\
\text { r. - Prawo celne), (Dz. U. nr } 75 \text {, poz. } 445 \text { z dnia } \\
\text { 31.12.1989) }\end{array}$ & 28.12 .1989 & 31.12 .1989 & 01.01 .1990 \\
\hline & $\begin{array}{l}\text { The Act regulated the responsibilities of } \\
\text { unemployment agencies. }\end{array}$ & $\begin{array}{l}\text { Act on Employment (Ustawa z dnia } 29 \text { grudnia } 1989 \mathrm{r} \text {. } \\
\text { o zatrudnieniu), (Dz. U. 1989, nr } 75 \text {, poz. } 446 \text { z dnia } \\
\text { 31.12.1989). }\end{array}$ & 29.12 .1989 & 31.12 .1989 & 31.12 .1989 \\
\hline & $\begin{array}{l}\text { Act guaranteed severance pay and temporary } \\
\text { unemployment benefits for those who lost their } \\
\text { jobs. }\end{array}$ & $\begin{array}{l}\text { Act on Special Circumstances of Laying off Workers } \\
\text { (Ustawa z dnia } 28 \text { grudnia } 1989 \text { r. o szczególnych } \\
\text { zasadach rozwiązywania z pracownikami stosunków } \\
\text { pracy z przyczyn dotyczących zakładu pracy oraz o } \\
\text { zmianie niektórych ustaw), (Dz. U. 1990, nr 4, poz. } 19 \\
\text { z dnia 27.01.1990) }\end{array}$ & 28.12 .1989 & 27.01 .1990 & 27.01 .1990 \\
\hline & In this period, three more acts strictly connected with & he Plan were passed. & & & \\
\hline & $\begin{array}{l}\text { The Act specified ways of privatizations and } \\
\text { conditions under which it can be conducted. }\end{array}$ & $\begin{array}{l}\text { Act on Privatization of State-owned companies } \\
\text { (Ustawa z dnia } 13 \text { lipca } 1990 \text { r. o prywatyzacji } \\
\text { przedsiębiorstw państwowych.), (Dz. U. 1990, nr 51, } \\
\text { poz. } 298 \text { z dnia 01.08.1990) }\end{array}$ & 13.07 .1990 & 01.08 .1990 & 01.08 .1990 \\
\hline & Dito & $\begin{array}{l}\text { (Ustawa z dnia } 13 \text { lipca } 1990 \text { r. o utworzeniu Ministra } \\
\text { Przekształceń Własnościowych), (Dz. U. 1990, nr } 51 \\
\text { poz. } 299 \text { z dnia 01.08.1990) }\end{array}$ & 13.07 .1990 & 01.08 .1990 & 01.08 .1990 \\
\hline & $\begin{array}{l}\text { The Act abolished the state monopoly in insurance } \\
\text { services. }\end{array}$ & $\begin{array}{l}\text { Act on Insurances (Ustawa z dnia } 28 \text { lipca } 1990 \text { r. o } \\
\text { działalności ubezpieczeniowej), (Dz. U. 1990, nr 59, } \\
\text { poz. } 344 \text { z dnia 28.08.1990) }\end{array}$ & 28.07 .1990 & 28.08 .1990 & 28.08 .1990 \\
\hline Krzysztof Bielecki & $\begin{array}{l}\text { Taxation development } \\
\text { The government passed three acts on taxation in }\end{array}$ & $\begin{array}{l}\text { Act on Personal Income Tax (Ustawa z dnia } 26 \text { lipca } \\
1991 \text { r. o podatku dochodowym od osób fizycznych), } \\
\text { (Dz. U. 1991, nr } 80 \text { poz. } 350 \text { z dnia } 10.09 .1991 \text { ) }\end{array}$ & 26.07 .1991 & 10.09 .1991 & 01.01 .1992 \\
\hline & $\begin{array}{l}\text { Poland. Acts introduced Personal Income Tax and } \\
\text { specified regulations on Corporate Income Tax, } \\
\text { local charges and other types of taxes (property tax }\end{array}$ & $\begin{array}{l}\text { Act on Taxes and Local Charges (Ustawa z dnia } 12 \\
\text { stycznia } 1991 \mathrm{r} \text {. o podatkach i opłatach lokalnych), } \\
\text { (Dz. U. 1991, nr 9, poz.31 z dnia 30.01.1991) }\end{array}$ & 12.01 .1991 & 30.01 .1991 & 30.01 .1991 \\
\hline & etc.). & $\begin{array}{l}\text { Act on Corporate Income Tax (Obwieszczenie } \\
\text { Ministra Finansów z dnia } 3 \text { czerwca } 1991 \mathrm{r} \text {. w sprawie } \\
\text { ogłoszenia jednolitego tekstu ustawy z dnia } 31 \\
\text { stycznia } 1989 \text { r. o podatku dochodowym od osób } \\
\text { prawnych.), (Dz.U. 1991, nr 49, poz. } 216 \text { z dnia } \\
\text { 11.06.1991) }\end{array}$ & 03.06 .1991 & 11.06 .1991 & 11.06 .1991 \\
\hline Jan Olszewski & & & & & \\
\hline Waldemar Pawlak I & & & & & \\
\hline
\end{tabular}




\begin{tabular}{|c|c|c|c|c|}
\hline \multirow[t]{2}{*}{ Hann Suchocka } & $\begin{array}{l}\text { Introducing Value Added Tax and Excise Tax } \\
\text { First steps to introduce VAT were taken by the } \\
\text { Government of Jan Krzysztof Bielecki but the Act } \\
\text { was rejected by the Sejm. On } 30^{\text {th }} \text { April } 1992 \text { started } \\
\text { the preparations on new act (Government of Jan } \\
\text { Olszewski). The Act was submittedto the Sejm in } \\
\text { June } 1992 \text { and passed on } 8^{\text {th }} \text { January } 1993 \text {. }\end{array}$ & $\begin{array}{l}\text { Act on VAT and Excise Tax (Ustawa z dnia } 8 \text { stycznia } \\
1993 \text { r. o podatku od towarów i usług oraz o podatku } \\
\text { akcyzowym), (Dz. U. 1993, nr 11, poz. 50) }\end{array}$ & 08.01 .1993 & 05.07 .1993 \\
\hline & $\begin{array}{l}\text { Privatization Program (Program Powszechnej } \\
\text { Prywatyzacji) } \\
\text { The new Act introduced regulations on National } \\
\text { Investment Funds. } \\
\text { Every citizen of Poland received special personal } \\
\text { voucher. Those vouchers could have been } \\
\text { exchanged into shares of companies, which were } \\
\text { part of National Investment Funds. } \\
\text { Duration of the Program was planned for the years } \\
1994 \text { to } 1998 \text {. }\end{array}$ & $\begin{array}{l}\text { Act on National Investment Funds and their } \\
\text { privatization (Ustawa z dnia } 30 \text { kwietnia } 1993 \text { r. o } \\
\text { narodowych funduszach inwestycyjnych i ich } \\
\text { prywatyzacji), (Dz. U. 1993, nr 44, poz. 202) }\end{array}$ & 30.04 .1993 & 13.06 .1993 \\
\hline \multirow[t]{2}{*}{ Waldemar Pawlak II } & $\begin{array}{l}\text { Strategy for Poland (Strategia dla Polski) } \\
\text { Main assumptions can be found in citation given in } \\
\text { the following footnote }{ }^{17} \text { : } \\
\text { The Strategy was being implemented till } 1997 \text { by } \\
\text { three following governments (The second } \\
\text { Government of WaldemarPawlak, the Government } \\
\text { of Józef Oleksy and Government of Włodzimierz } \\
\text { Cimoszewicz). In all of those governments the } \\
\text { Minister of Finance was Grzegorz Kołodko (one of } \\
\text { the authors of the Strategy). }\end{array}$ & $\begin{array}{l}\text { The Strategy did not assume introducing big changes } \\
\text { in law. }\end{array}$ & & \\
\hline & $\begin{array}{l}\text { Redenomination } \\
\text { Already in } 1989 \text {, there was first conception of } \\
\text { redenomination. On } 17^{\text {th }} \text { July } 1990 \text {, the Head of } \\
\text { National Bank informed about this idea. From } \\
\text { December } 1990 \text { to February } 1992 \text { first banknotes } \\
\text { and coins were issued but because of forgeries in } \\
1992 \text { and } 1993 \text {, new security feature had to be } \\
\text { introduced }^{18} \text {. }\end{array}$ & $\begin{array}{l}\text { Act on Redenomination (Ustawa z dnia } 7 \text { lipca } 1994 \text { r. } \\
\text { o denominacji złotego), (Dz. U. } 1994 \text { nr } 84 \text { poz. 386) }\end{array}$ & 07.07 .1994 & 01.01 .1995 \\
\hline
\end{tabular}

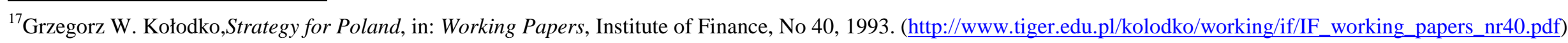

${ }^{18}$ www.muzhp.pl (Muzeum Historii Polski) 


\begin{tabular}{|c|c|c|c|c|c|}
\hline & $\begin{array}{l}\text { The Act on Redenomination was passed on } 7^{\text {th }} \text { July } \\
1994 \text {. }\end{array}$ & & & & \\
\hline \multicolumn{6}{|l|}{ Józef Oleksy } \\
\hline \multicolumn{6}{|l|}{$\begin{array}{l}\text { Włodzimierz } \\
\text { Cimoszewicz }\end{array}$} \\
\hline \multirow[t]{5}{*}{ Jerzy Buzek } & \multirow{3}{*}{$\begin{array}{l}\text { Pension System Reform - introduction of new, } \\
\text { actuarially fair old-age pensions system that } \\
\text { replaced ineffective defined-benefit system. The } \\
\text { new system consists of } 3 \text { pillars: the PAYG system } \\
\text { managed by FUS (Social Insurance Fund managed } \\
\text { by ZUS), the capital pillar managed by Open Old- } \\
\text { Age Pensions Funds (OFEs) and voluntary } \\
\text { individual retirement savings. The contribution rate } \\
\text { was set at } 19,22 \% \text { ( } 7 \% \text { for OFE), paid in equal parts } \\
\text { by employees and employers. The new system is } \\
\text { compulsory (with some exceptions) for all non- } \\
\text { farmers born in } 1949 \text { and later. Some occupational } \\
\text { groups (i.e. miners or police officers) remained } \\
\text { privileged. There is also a separated pension system } \\
\text { for soldiers. } \\
\text { The second big pension system in Poland is for } \\
\text { farmers and their families and is managed by KRUS } \\
\text { (KasaRolniczegoUbezpieczeniaSpołecznego). They } \\
\text { pay very little pension contribution, receive smaller } \\
\text { benefits and the whole system is practically } \\
\text { financed by the state budget. }\end{array}$} & $\begin{array}{l}\text { Act on the Social Security System } \\
\text { (Ustawa z dnia } 13 \text { października } 1998 \text { r. o systemie } \\
\text { ubezpieczeń społecznych), (Dz. U. } 1998 \text { nr } 137 \text { poz. } \\
887 \text { z dnia } 10 \text { listopada } 1998 \text { r.), }\end{array}$ & 13.10 .1998 & & 01.01 .1999 \\
\hline & & $\begin{array}{l}\text { Act on Pensions } \\
\text { (Ustawa z dnia } 17 \text { grudnia } 1998 \text { o emeryturach i } \\
\text { rentach z Funduszu Ubezpieczeń Społecznych), (Dz. } \\
\text { U. } 1998 \text { nr } 162 \text { poz. 1118) }\end{array}$ & \multirow[t]{2}{*}{17.12 .1998} & & \multirow[t]{2}{*}{01.01 .1999} \\
\hline & & & & & \\
\hline & Education System Reform & $\begin{array}{l}\text { Act on Education System } \\
\text { (Ustawa z dnia } 8 \text { stycznia } 1999 \text { r. - Przepisy } \\
\text { wprowadzające reformę ustroju szkolnego), (Dz. U. } \\
1999 \mathrm{nr} \text { 12, poz. 96) }\end{array}$ & 08.01 .1999 & & 27.02 .1999 \\
\hline & $\begin{array}{l}\text { Health Care System Reform } \\
\text { Health Care System decentralization }\end{array}$ & $\begin{array}{l}\text { Act on Change in Public Health Care System } \\
\text { (Ustawa z dnia } 3 \text { grudnia } 1999 \text { r. o zmianie ustawy o } \\
\text { powszechnym ubezpieczeniu zdrowotnym), (Dz. U. } \\
1999 \mathrm{nr} 109 \text {, poz. 1236) }\end{array}$ & 03.12 .1999 & 29.12 .1999 & 29.12 .1999 \\
\hline
\end{tabular}




\begin{tabular}{|c|c|c|c|c|c|}
\hline & $\begin{array}{l}\text { Administration Reform } \\
\text { Introduction of 3-Stage administrative division of } \\
\text { the country (gmina, powiat, województwo). New } \\
\text { administrative division was valid since } 1^{\text {st }} \text { January } \\
\text { 1999.The number of województwa was reduced } \\
\text { from } 49 \text { to } 16 \text {. }\end{array}$ & $\begin{array}{l}\text { Act on Administrative Division of Poland } \\
\text { (Ustawa z dnia } 24 \text { lipca } 1998 \mathrm{r} \text { o o wprowadzeniu } \\
\text { trójstopniowego podziału terytorialnego państwa), } \\
\text { (Dz. U. } 1998 \mathrm{nr} 96 \text { poz. 603) }\end{array}$ & 24.07.1998 & 28.07 .1998 & 28.07.1998 \\
\hline Leszek Miller & $\begin{array}{l}\text { Hausner Plan (Plan Hausnera) } \\
\text { The Hausner Plan was a package of acts. Its aim } \\
\text { was to improve the condition of public sector } \\
\text { finances. The Plan assumed inter alia: changes in } \\
\text { pension and benefit valorization, reform of the } \\
\text { Agricultural Social Insurance Fund (KRUS), } \\
\text { reorganizing sickness and disability benefits, } \\
\text { imposing higher social insurance contribution } \\
\text { requirements on the self employment, pushing up } \\
\text { the retirement age for women to } 65 \text {. } \\
\text { Despite the fact that the Government of } \\
\text { MarekBelka continued implementation of the Plan, } \\
\text { the largest part of it was newer introduced. }\end{array}$ & & & & \\
\hline \multicolumn{6}{|l|}{ Marek Belka I } \\
\hline Marek Belka & & & & & \\
\hline $\begin{array}{l}\text { Kazimierz } \\
\text { Marcinkiewicz }\end{array}$ & $\begin{array}{l}\text { The government started preparation of the Public } \\
\text { Finance Reform and changes in taxation. The } \\
\text { Minister of Finance was ZytaGilowska (from 22th } \\
\text { September } 2006 \text { to } 7^{\text {th }} \text { September 2007), a former } \\
\text { member of PO. }\end{array}$ & & & & \\
\hline Jarosław Kaczyński & $\begin{array}{l}\text { The preparations of Reform were continued. The } \\
\text { Minister of Finance was again ZytaGilowska (from } \\
10^{\text {th }} \text { September } 2007 \text { to } 16^{\text {th }} \text { November 2007). } \\
\text { The Program of the Reforms assumed inter alia: } \\
\checkmark \text { The consolidation of the public sector and } \\
\text { local government budgets; } \\
\checkmark \text { Removal of all special-purpose funds } \\
\text { handled by local governments; } \\
\checkmark \text { Transparency in the spending of public } \\
\text { funds; } \\
\checkmark \quad \text { Introduction of the audit at central } \\
\text { institutions and larger local governmental } \\
\text { units; } \\
\checkmark \text { The reduction of disability and survivals' } \\
\text { pension contribution (składkarentowa), }\end{array}$ & & & & \\
\hline
\end{tabular}




\begin{tabular}{|c|c|c|c|c|c|}
\hline & $\begin{array}{l}\text { (first reduction on } 1^{\text {st }} \text { July 2007, second } \\
\text { one on } 1^{\text {st }} \text { January } 2008 \text { ) } \\
\checkmark \quad \text { The treatment of EU funds as state budget } \\
\text { revenue; }\end{array}$ & & & & \\
\hline \multirow[t]{2}{*}{ Donald Tusk I } & $\begin{array}{l}\text { The government passed on } 27 \text { th August } 2009 \text { Act } \\
\text { on Public Sector Finances. } \\
\text { The Act scrapped most of central and local } \\
\text { governmental budget unities. It obligated the } \\
\text { government to prepare Multi-year National } \\
\text { Financial Plans spanning four years and an official } \\
\text { budget of EU funds. The Act retains also three } \\
\text { safety thresholds for the public debt (at } 50 \% \text {, 55\% } \\
\text { and } 60 \% \text { of GDP) which trigger mandatory fiscal } \\
\text { adjustment. } \\
\text { In } 2010 \text { the amendment for the Act was passed. } \\
\text { The amendment introduced expenditure rule. } \\
\text { According to that rule, discretionary and new fixed } \\
\text { expenditures may not grow by more than } 1 \% \text { in real } \\
\text { term annually. The next change was introduction of } \\
\text { medium-term planning, also in local governments. } \\
\text { The amendment introduced also an additional } \\
\text { mechanism for protecting public finances through } \\
\text { the introduction of conditional VAT rate rises. }\end{array}$ & $\begin{array}{l}\text { Act on Public Sector Finances (Ustawa z dnia } 27 \\
\text { sierpnia } 2009 \text { r. o finansach publicznych), (Dz. U. } \mathrm{Nr} \\
157 \text { poz. 1240) }\end{array}$ & 27.08 .2009 & 24.09 .2009 & 01.01 .2010 \\
\hline & $\begin{array}{l}\text { The abolition of early retirement privilege for some } \\
\text { occupational groups and introduction of old-age } \\
\text { pensions paid to older workers, who retired before } \\
\text { the standard retirement age (bridge benefit). } \\
\text { Reduction of the part of old-age pension } \\
\text { contribution of the second, capital pillar (OFEs) } \\
\text { from } 7 \% \text { to 3,5\% percent (the reduction for the first } \\
\text { few years is bigger). This part of SSC will be used } \\
\text { to pay current old-age pensions but can be inherited, } \\
\text { just like the money in OFEs. Introduction of higher } \\
\text { limits on investing in stocks for OFEs. }\end{array}$ & $\begin{array}{l}\text { Act on Bridge Benefis (Ustawa z dnia } 19 \text { grudnia } 2008 \\
\text { r. o emeryturach pomostowych), (Dz. U. } 2008 \mathrm{nr} 237 \\
\text { poz. 1656) } \\
\text { Act on Change in Pension System (Ustawa z dnia } 25 \\
\text { marca } 2011 \text { r. o zmianie niektórych ustaw związanych } \\
\text { z funkcjonowaniem systemu ubezpieczeń } \\
\text { społecznych), (Dz. U. } 2011 \text { nr } 75 \text { poz.398) }\end{array}$ & $\begin{array}{r}19.12 .2008 \\
25.03 .2011\end{array}$ & $\begin{array}{l}31.12 .2008 \\
08.04 .2011\end{array}$ & $\begin{array}{l}01.01 .2009 \\
01.05 .2011\end{array}$ \\
\hline
\end{tabular}




\begin{tabular}{|c|c|c|c|c|c|}
\hline & $\begin{array}{l}\text { Raising the VAT rates up by } 1 \text { percentage } \\
\text { point(from } 7 \text { to } 8 \text { percent and from } 22 \text { to } 23 \text { percent) }\end{array}$ & $\begin{array}{l}\text { Act on changes on acts connected with } \\
\text { implementation of budget act(Ustawa z dnia } 26 \\
\text { listopada } 2010 \text { r. o zmianie niektórych ustaw } \\
\text { związanych z realizacją ustawy budżetowej), (Dz. U. } \\
2010 \text { nr } 238 \text { poz. 1578) }\end{array}$ & 26.11 .2010 & 17.12 .2010 & 01.01 .2011 \\
\hline Donald Tusk II & $\begin{array}{l}\text { Introduction of tax on selected fossils (silver and } \\
\text { copper) (budget) } \\
\text { Raising up the disability and survival pension } \\
\text { contribution (składkarentowa) by } 2 \text { percentage } \\
\text { points (budget) } \\
\text { Pushing up the retirement age of men and women to } \\
67 \text { years (in } 2020 \text { for males and } 2040 \text { for females) } \\
\text { (expose) } \\
\text { Reduction of old-age pension privileges of selected } \\
\text { state employees, mainly the police, prison guards } \\
\text { etc. (expose) } \\
\text { Plans of changes in the money transfers between } \\
\text { FUS (Social Insurance Fund, managed by ZUS), } \\
\text { state } \\
\text { (OtwarteFunduszeEmerytalne, Ond Open Old-Age } \\
\text { Pension Funds, the companies managing the part of } \\
\text { old-age pension contributions in the second, capital } \\
\text { pillar): since } 1999 \text {, the whole old-age pension } \\
\text { contributions have been collected by ZUS and a part } \\
\text { of it has been transferred monthly to OFEs (in cash } \\
\text { or more precisely- as bank transfers). The state } \\
\text { budget transfers money in this amounth back to } \\
\text { ZUS. Minister of Administration and IT } \\
\text { Development (Ministerstwo Administracji i } \\
\text { Cyfryzacji) is working on introduction of long-term } \\
\text { state bonds (pension bonds) that should replace } \\
\text { money transfers to OFEs, so as to reduce the } \\
\text { borrowing needs of the state and, consequently, also } \\
\text { public sector deficit and public debt. }\end{array}$ & $\begin{array}{l}\text { Project of Budget Act for } 2012 \\
\text { Projekt Ustawy budżetowej na rok 2012, przyjęty } \\
\text { przez Radę Ministrów 6.12.2011, } \\
\text { Expose of Prime Minister Donald Tusk, 18.11.2011 } \\
\text { http://www.premier.gov.pl/files/download/5678.pdf }\end{array}$ & & & \\
\hline
\end{tabular}

Sources: http://isap.sejm.gov.pl/; www.money.pl; www.pb.pl; www.obserwatorfinansowy.pl; www.gazeta.pl; www.wikipedia.pl; www.premier.gov.pl. 
Table 2. Evolution of dispersion of wages: France, Poland and United States

\begin{tabular}{llcccccccc}
\hline Time & & 1992 & 1994 & 1996 & 1998 & 2000 & 2002 & 2004 & 2006 \\
\hline Country & & & & & & & & & \\
\hline France & Low Pay Incidence* &.. &.. &.. &.. &.. &.. &.. &.. \\
& Decile 5/Decile 1 & 1,6 & 1,6 & 1,6 & 1,6 & 1,5 & 1,5 & 1,5 &.. \\
& Decile 9/Decile 1 & 3,2 & 3,1 & 3,1 & 3,1 & 3,0 & 3,0 & 3,0 &.. \\
\multirow{4}{*}{ Poland } & Decile 9/Decile 5 & 2,0 & 1,9 & 1,9 & 1,9 & 2,0 & 2,0 & 2,0 &.. \\
& Low Pay Incidence* & 14,3 & 17,6 & 18,4 & 18,8 &.. & 22,1 & 23,5 &.. \\
& Decile 5/Decile 1 & 1,6 & 1,7 & 1,8 & 1,8 &.. & 2,0 & 2,0 &.. \\
& Decile 9/Decile 1 & 2,9 & 3,4 & 3,5 & 3,5 &.. & 4,1 & 4,2 &.. \\
United State & Decile 9/Decile 5 & 1,8 & 2,0 & 2,0 & 2,0 &.. & 2,1 & 2,2 &.. \\
& Low Pay Incidence* & 23,2 & 25,1 & 25,1 & 24,5 & 24,7 & 23,5 & 23,9 & 24,2 \\
& Decile 5/Decile 1 & 2,1 & 2,1 & 2,1 & 2,0 & 2,1 & 2,1 & 2,1 & 2,1 \\
& Decile 9/Decile 1 & 4,4 & 4,5 & 4,6 & 4,5 & 4,5 & 4,7 & 4,8 & 4,8 \\
& Decile 9/Decile 5 & 2,1 & 2,2 & 2,2 & 2,2 & 2,2 & 2,3 & 2,3 & 2,3 \\
\hline
\end{tabular}

Source: OECD. *Less than two-thirds of median earnings of all workers. 


\section{Appendix}

Table A1. Polish governments and their party composition plus composition of opposition parties

\begin{tabular}{|c|c|c|c|c|c|}
\hline $\begin{array}{l}\text { Government } \\
\text { (Prime Minister) }\end{array}$ & Duration & $\begin{array}{l}\text { Tenure of } \\
\text { the Sejm }\end{array}$ & Coalition & Opposition & Comment \\
\hline Tadeusz Mazowiecki & $\begin{array}{l}24.08 .1989- \\
25.11 .1990\end{array}$ & $\mathrm{X}$ & Solidarność - ZSL - PZPR - SD & & In 1990 ZSL transformed into PSL. \\
\hline $\begin{array}{l}\text { Jan Krzysztof } \\
\text { Bielecki }\end{array}$ & $\begin{array}{l}\text { 12.01.1991- } \\
05.12 .1991\end{array}$ & $\mathrm{X}$ & $\mathrm{KLD}-\mathrm{ZChN}-\mathrm{PC}-\mathrm{SD}$ & & \\
\hline Jan Olszewski & $\begin{array}{l}23.12 .1991- \\
05.06 .1992\end{array}$ & I & $\mathrm{PC}-\mathrm{ZChN}-\mathrm{PSL}-\mathrm{PL}$ & $\mathrm{UD}, \mathrm{KLD}, \mathrm{PPG}$ & \\
\hline Waldemar Pawlak I & $\begin{array}{l}05.06 .1992- \\
07.07 .1992\end{array}$ & I & PSL & & \\
\hline Hanna Suchocka & $\begin{array}{l}11.07 .1992- \\
18.10 .1993\end{array}$ & $\mathrm{I}$ & $\begin{array}{l}\mathrm{UD}-\mathrm{KLD}-\mathrm{ZChN}-\mathrm{PChD}- \\
\mathrm{PPPP}-\mathrm{PSL}-\mathrm{PL}\end{array}$ & SdRP & SdRP was a predecessor of SLD. \\
\hline Waldemar Pawlak II & $\begin{array}{l}26.10 .1993- \\
01.03 .1995\end{array}$ & II & SLD - PSL - BBWR & UD, UP & $\begin{array}{l}\text { In } 1994 \text { KLD and UD joint together and } \\
\text { established UW. }\end{array}$ \\
\hline Józef Oleksy & $\begin{array}{l}06.03 .1995- \\
26.01 .1996\end{array}$ & II & SLD - PSL & UP, UW & \\
\hline $\begin{array}{l}\text { Włodzimierz } \\
\text { Cimoszewicz }\end{array}$ & $\begin{array}{l}07.02 .1996- \\
17.10 .1997\end{array}$ & II & SLD - PSL & UP, UW & \\
\hline Jerzy Buzek & $\begin{array}{l}31.10 .1997- \\
19.10 .2001\end{array}$ & III & AWS - UW & PSL, SLD & At the end of tenure UW left the coalition. \\
\hline Leszek Miller & $\begin{array}{l}\text { 19.10.2001- } \\
02.05 .2004\end{array}$ & IV & SLD - UP - PSL & PO, PiS, LPR, Samoobrona & $\begin{array}{l}\text { PO and PiS have their origins in former } \\
\text { coalition AWS-UW. }\end{array}$ \\
\hline Marek Belka I & $\begin{array}{l}\text { 02.05.2004- } \\
19.05 .2004\end{array}$ & IV & SLD - UP & $\begin{array}{l}\text { PSL, PO, PiS, LPR, SDPL, } \\
\text { Samoobrona }\end{array}$ & \\
\hline Marek Belka II & $\begin{array}{l}11.06 .2004- \\
19.10 .2005 \\
\end{array}$ & IV & SLD - UP & $\begin{array}{l}\text { PSL, PO, PiS, LPR, SDPL, } \\
\text { Samoobrona }\end{array}$ & \\
\hline $\begin{array}{l}\text { Kazimierz } \\
\text { Marcinkiewicz }\end{array}$ & $\begin{array}{l}\text { 31.10.2005- } \\
10.07 .2006\end{array}$ & $\mathrm{~V}$ & PiS - Samoobrona - LPR & PO, PSL, SLD & \\
\hline Jarosław Kaczyński & $\begin{array}{l}\text { 14.07.2006- } \\
05.11 .2007\end{array}$ & $\mathrm{~V}$ & PiS - Samoobrona - LPR & PO, SLD, PSL & \\
\hline Donald Tusk I & $\begin{array}{l}\text { 16.11.2007- } \\
18.11 .2011\end{array}$ & VI & $\mathrm{PO}-\mathrm{PSL}$ & PiS, SLD & \\
\hline Donald Tusk II & 18.11.2011- & VII & $\mathrm{PO}-\mathrm{PSL}$ & PiS, SLD, RP, SP & \\
\hline
\end{tabular}




\section{Explanations for party labels}

AWS - Akcja Wyborcza Solidarność (Solidarity Electoral Action)

BBWR - Bezpartyjny Blok Wspierania Reform (Nonpartisan Bloc for Support of Reforms)

KLD - Kongres Liberalno-Demokratyczny (Liberal Democratic Congress)

LPR - Liga Polskich Rodzin (League of Polish Families)

PC - Porozumienie Centrum (Centre Agreement)

PChD - Partia Chrześcijańskich Demokratów (Party of Christian Democrats)

PiS - Prawo i Sprawiedliwość (Law and Justice)

$\mathrm{PL}$ - Porozumienie Ludowe (People's Agreement)

PO - Platforma Obywatelska (Civic Platform)

PPPP - Polska Partia Przyjaciół Piwa (Polish Beer-Lovers' Party)

PSL - Polskie Stronnictwo Ludowe (Polish People's Party)

PZPR - Polska Zjednoczona Partia Robotnicza, (Polish United Workers' Party)

RP - Ruch Palikota (Palikot's Movement)

Samoobrona Rzeczpospolitej Polskiej - Self-Defense of the Republic of Poland

$S D$ - Stronnictwo Demokratyczne (Alliance of Democrats)

SDPL - Socjaldemokracja Polska (Social Democracy of Poland)

SLD - Sojusz Lewicy Demokratycznej (Democratic Left Alliance)

SP - Solidarna Polska (United Poland)

UD - Unia Demokratyczna (Democratic Union)

UP - Unia Pracy (Labour Union)

UW - Unia Wolności (Freedom Union)

ZChN - Zjednoczenie Chrześcijańsko-Narodowe (Christian National Union)

ZSL - Zjednoczone Stronnictwo Ludowe, (United People's Party) 


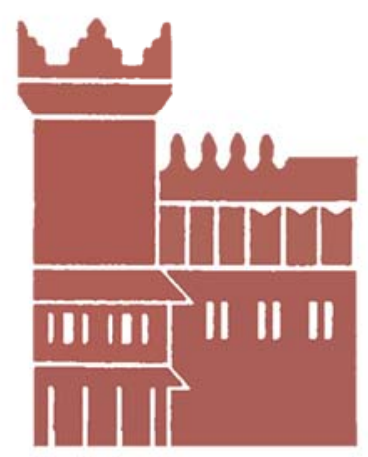

Alma Mater Studiorum - Università di Bologna DEPARTMENT OF ECONOMICS

Strada Maggiore 45

40125 Bologna - Italy

Tel. +39051 2092604

Fax +390512092664

http://www.dse.unibo.it 